\title{
Value chain analysis of the potato sector in Tunisia
}

Business opportunities

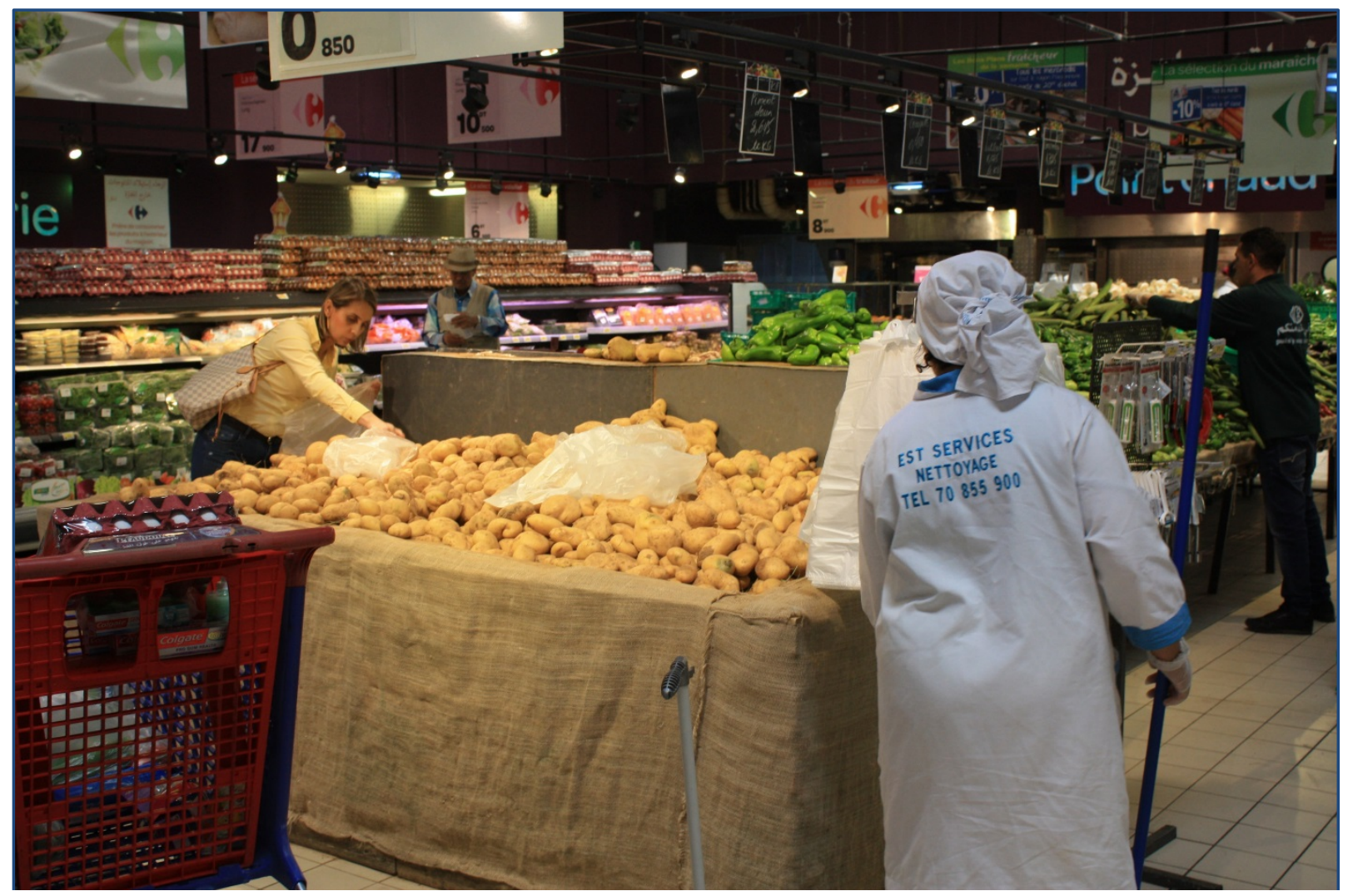

Greet Blom-Zandstra, Han Soethoudt, Heike Axmann

Wageningen University \& Research

This study was carried out by the Wageningen Research Foundation (WR) and was commissioned by Rijksdienst voor Ondernemend Nederland (RVO) and financed by the Dutch Ministry of Foreign Affairs. Project title: Chain analysis / business opportunities potato sector Tunisia (MAT18TN03).

WR is part of Wageningen University \& Research, the collaboration of Wageningen University and Wageningen Research Foundation.

Wageningen, June 2018

Report WPR-804 
Blom-Zandstra, G., H. Soethoudt, H. Axmann, 2018. Value chain analysis of the potato sector in Tunisia. Business opportunities. Wageningen Research, Report WPR-804

This report can be downloaded for free at https://doi.org/10.18174/452933

Keywords: Value chain, potato, SWOT-analysis, knowledge gaps, business opportunities, Tunisia

(C) 2018 Wageningen, Stichting Wageningen Research, Wageningen Plant Research, Business Unit Agrosystems, P.O. Box 16, 6700 AA Wageningen, The Netherlands; T +31 (0)317 480700 ; www.wur.eu/plant-research

Chamber of Commerce no. 09098104 at Arnhem

VAT NL no. 8065.11.618.B01

Stichting Wageningen Research. All rights reserved. No part of this publication may be reproduced, stored in an automated database, or transmitted, in any form or by any means, whether electronically, mechanically, through photocopying, recording or otherwise, without the prior written consent of the Stichting Wageningen Research.

Stichting Wageningen Research is not liable for any adverse consequences resulting from the use of data from this publication.

Report WPR-804

Photo cover: Greet Blom-Zandstra

All pictures in this report are made by Greet Blom-Zandstra, unless otherwise stated 


\section{Contents}

$\begin{array}{ll}\text { Preface } & 5\end{array}$

$\begin{array}{ll}\text { Summary } & 7\end{array}$

1

$\begin{array}{ll}\text { Introduction } & 9\end{array}$

2

$\begin{array}{ll}\text { Tunisia profile } & 11\end{array}$

2.1 Geography 11

2.2 Population 11

$\begin{array}{lll}2.3 & \text { Economy } & 12\end{array}$

$\begin{array}{lll}2.4 & \text { Climate } & 14\end{array}$

$\begin{array}{lll}2.5 & \text { Policy trends in food and agriculture } & 15\end{array}$

3

$\begin{array}{ll}\text { Potato sector } & 17\end{array}$

$\begin{array}{lll}3.1 & \text { Potato production and sale } & 17\end{array}$

$\begin{array}{lll}3.2 & \text { Potato sector in social context } & 20\end{array}$

$\begin{array}{ll}\text { The pricing system } & 21\end{array}$

$\begin{array}{ll}\text { Analysis of the potato chain } & 22\end{array}$

$\begin{array}{lll}5.1 & \text { SWOT analysis } & 22\end{array}$

5.2 Proposals to strengthen these weak points $\quad 23$

6 Opportunities for the Dutch agricultural sector $\quad 25$

$6.1 \quad$ Equipment and knowhow to produce seed locally 25

$\begin{array}{lll}6.2 & \text { Processing of potatoes within the chain } & 26\end{array}$

$\begin{array}{lll}6.3 & \text { Farming equipment suitable for small fields } & 27\end{array}$

$\begin{array}{lll}6.4 & \text { Actors for business opportunities } & 27\end{array}$
6.4.1 Dutch actors
27
6.4.2 Tunisian actors $\quad 28$

7

Doing business in Tunisia $\quad 29$

$\begin{array}{lll}7.1 & \text { Business environment } & 29\end{array}$

$\begin{array}{lll}7.2 & \text { Starting a business } & 30\end{array}$

$\begin{array}{lll}7.3 & \text { Experience from Dutch investors } & 31\end{array}$

$8 \quad$ Conclusions $\quad 33$

References $\quad 34$

$\begin{array}{lll}\text { Annex } 1 & \text { Organisations and contacts } & 36\end{array}$

$\begin{array}{lll}\text { Annex } 2 & \text { Persons and organisations visited } & 39\end{array}$ 



\section{Preface}

At a conference in Tunis in 2017, representatives from FAO, the Tunisian Ministry of Agriculture, Fisheries and Water Resources and Wageningen University \& Research (WUR) concluded that the sustainable development of Tunisia's agriculture was currently hindered by a number of obstacles. The three parties further concluded that the support of FAO and Netherlands knowledge on sustainable agricultural development could help to tackle these obstacles.

Therefore, Netherlands Embassy in Tunis and the Tunisian Ministry of Agriculture, Fisheries and Water Resources organized an exploratory mission led by three experts from WUR to evaluate the situation and to further identify the needs and key priorities. From this needs assessment it was learned that Tunisia has high ambitions to innovate the agricultural sector towards a high level of produce and export, capable to comply with the EU regulations and to resist climate change. Although Tunisia has ample knowledge and skills in various agricultural areas on meta level the country is lacking a value chain approach, shows a lack of access to knowledge and investment capital and has no strategy on climate change. The needs assessment showed that following needs and priorities in Tunisia can be considered:

1. For climate smart agriculture: increase water availability, reduce the need for water

2. For soil: decrease degradation, increase fertility

3. For primary production:

a. sustainable innovations at multiple level in horticulture

b. improve seed quality and introduce storage facilities in potato produce

c. improve continuity in production for the market and create added value by processing in the dairy sector

4. For the general supply chain: introduce a market driven approach

5. Farmer-inclusive agri-business development: organise farmers towards an efficient market orientation

In March 2018, the cooperation between Tunisia and the Netherlands was further strengthened by the signing of a Letter of Intent by the Tunisian Minister of Agriculture, Fisheries and Water Resources and the Dutch Minister of Foreign Affairs, in which further study and development of various sectors of the agriculture were mentioned. The value chain of potato was one of these subjects.

In order to support the Tunisian government in their agricultural goals for the coming years, the Netherlands Embassy in Tunis requested for a value chain analysis and a business opportunity report for the potato sector. Aim of this study was to identify weak points in the value chain and to provide insights in how to tackle these weak points, to stimulate social and technical innovations and to provide guideline's how to increase the level of organisation between smallholders, where possible with participation of the Dutch private sector and knowledge sectors.

The authors of this business opportunity report wish that it may help to increase the smallholders" access to knowledge on good agricultural practice, to new sustainable technology and to market demands. And that it may also increase their access to money for investment in technical development and increase their awareness of the need to shift towards sustainable farm management and care for the environment.

J une 2018 


\section{Summary}

Agriculture plays a leading role in Tunisia's economy, with approximately $16 \%$ of the country's workforce engaged in the agricultural sector. Even though agriculture is an important sector in the Tunisian economy, the sector faces major challenges and Tunisia still depends on food imports. The government of Tunisia is looking for opportunities to increase national food production fitting the current and future climatic conditions. This would strengthen national food and nutrition security, generate employment and income, and save costs through import substitution.

Currently, Tunisian agriculture is in a transition phase from traditional agricultural systems to innovative sustainable agricultural systems. The focus of the government is mainly on the smallholders as they present the majority of the farmers and are the biggest future challenge.

The potato sector is an important sector in Tunisia. Potatoes represent the second crop in the country after tomatoes and is one of the staple foods in the Tunisian diet. This study describes a Tunisia profile and the development of the value chain of the potato sector, based on a literature survey and interviews with key players in the potato sector executed during a field mission hold from May $5^{\text {th }}$ until May $12^{\text {th }}, 2018$.

From the study, it appears that the value chain for potato is not fully developed. The main focus of the potato chain is on primary production. Most of the produced potatoes are directly consumed, while processing of potatoes hardly occurs. Currently, future perspectives for small holders appear to be unfavourable. As main problems in the potato sector can be considered: dependency on import of seed potatoes, variability in supply, fluctuation in the price system, low level of mechanisation and yield losses. Often prices are too low to offer the farmer a return on investment, while imported potatoes can be even cheaper. Weak points that complicate the potato chain are: insufficient transparency, distrust, no long-term perspective, parallel illegal and corrupt chains, no organisation and no registration.

However, the SWOT analysis show that there are different opportunities for innovation of the sector and improvement of the living of the potato small holder. Important opportunities for improvement of the sector are the introduction of equipment for mechanisation and adequate storage facilities. To make the sector more transparent and professional, the introduction of a registration system is proposed, as well as the setting up of a network in which farmers can share knowledge, can get guidance and education and can be trained in farmer entrepreneurship to organise farmers towards an efficient market orientation. To affect the pricing system, following measures to be taken by the government are mentioned:

1) Introduction of subsidies for potato farmers, based on a proper registration system and

2) Liberalisation of market prices.

As an incentive for famers, it is suggested to provide subsidies to farmers via farmer's based organisations, newly set up and clean. As support from the Netherlands is was requested to help to work towards a produce of $100 \%$ potato seeds locally, further to help to develop the value chain and supply of mechanisation and guidelines for handling.

In this study, two business cases were elaborated on 1) Equipment and knowhow to produce all seed potatoes locally and 2) Development of the processing of potatoes within the chain (Chips, French fries). Moreover, ideas were launched on the introduction of Equipment suitable for small fields. Actors for the business opportunities, both local and Dutch, were identified and finally, the attractiveness of Tunisia to Dutch companies is described. 


\section{Introduction}

Agriculture plays a leading role in Tunisia's economy, with approximately $16 \%$ of the country's workforce engaged in the agricultural sector. Historically, Tunisia's agricultural system was based on small family farms that grew subsistence crops with little market integration, but larger agricultural enterprises are increasingly prominent. Public land may be leased by the government to private farmers or managed directly by the Ministry of Agriculture. Foreigners cannot own agricultural land but may obtain long-term leases.

Even though agriculture is an important sector in the Tunisian economy, the sector faces major challenges and Tunisia still depends on food imports. The government of Tunisia is looking for opportunities to increase national food production fitting the rapidly changing climatic conditions and the associated increase in mean temperatures and water stress. This would strengthen national food and nutrition security, generate employment and income, and save costs through import substitution. To achieve this, the Tunisian government launched an agriculture and rural development strategy and a five years implementation plan to open up the local market internationally and import knowledge and experience in order to help the local economy.

The Netherlands is the second large exporter of agricultural products in the world, and has a very advanced knowledge when it comes to agriculture. Education and research in the Netherlands has resulted in significant value creation and a high degree of sustainability in various production chains. This requires a highly efficient system that incorporates new scientific insights continuously. A system in which research institutes collaborate closely with industry (including farmers), government and civil society.

Currently, Tunisian agriculture is in a transition phase from traditional agricultural systems to innovative sustainable agricultural systems. The focus of the government is mainly on the smallholders as they present the majority of the farmers and are therefore the biggest future challenge. Government wants to provide solutions in terms of supply chain management, clustering of farmers, adding value to the products, etc. Medium and entrepreneurial farmers are an interesting target group for the Tunisian government for modernisation and transformation of the sector, and they could become the motor of change in Tunisia.

The potato sector is an important sector in Tunisia. Potatoes have a significant contribution to the production value and belong to one of the staple foods in the Tunisian diet. Potatoes are grown on around 27,000 ha of sandy soils and production is $370 \mathrm{MT} /$ year. This is about $17 \%$ of the county's cultivated land. However, $90 \%$ of the farmers plant contain less than 1 ha of potato, and only $10 \%$ of the producers plant more than 3-4 ha. Yields of smallholders are low due to lack of: implementation of GAP, access to buy inputs, mechanisation and proper stock conditions. The total need for seed potatoes in Tunisia is much higher than the national production can supply, forcing Tunisia to import part of the needed seeds. However, it is a Tunisian goal to become totally independent on imports.

In 2017 a Needs Assessment, commissioned by the Netherlands Embassy in Tunisia and the Tunisian Ministry of Agriculture, Fisheries and Water Resources (Blom et al, 2017) has been performed to identify and analyse the agricultural problems in the North and North-West of Tunisia. This study described as main challenges for the potato sector following:

- A need for import of seed potato due to insufficient production and inadequate stock conditions

- Limited yields in production

- Lack of technology

- Limited knowhow on technology and postharvest management

- High percentage of losses

- No well-developed supply chains

- Low organizational rate of the farmers 
To support the Tunisian authorities in developing a sustainable potato sector, the Regional Agricultural Office for the Magreb of the Embassy of the Kingdom of the Netherlands asked for a value chain analysis to identify flaws and challenges in the potato value chain and to provide the potato sector with ideas for value adding, improving the sustainability in the value chain of potatoes and better control of markets by farmers. In this report the results of the value chain analysis of the potato chain in North and North West Tunisia are presented and will indicate at what junctions the NL private sector could participate in this process of making chains more sustainable. This study comprises the current situation of the potato sector, the most important players of the sector, a SWOT analysis, the role of the government policy in potato production and opportunities for Dutch companies to participate.

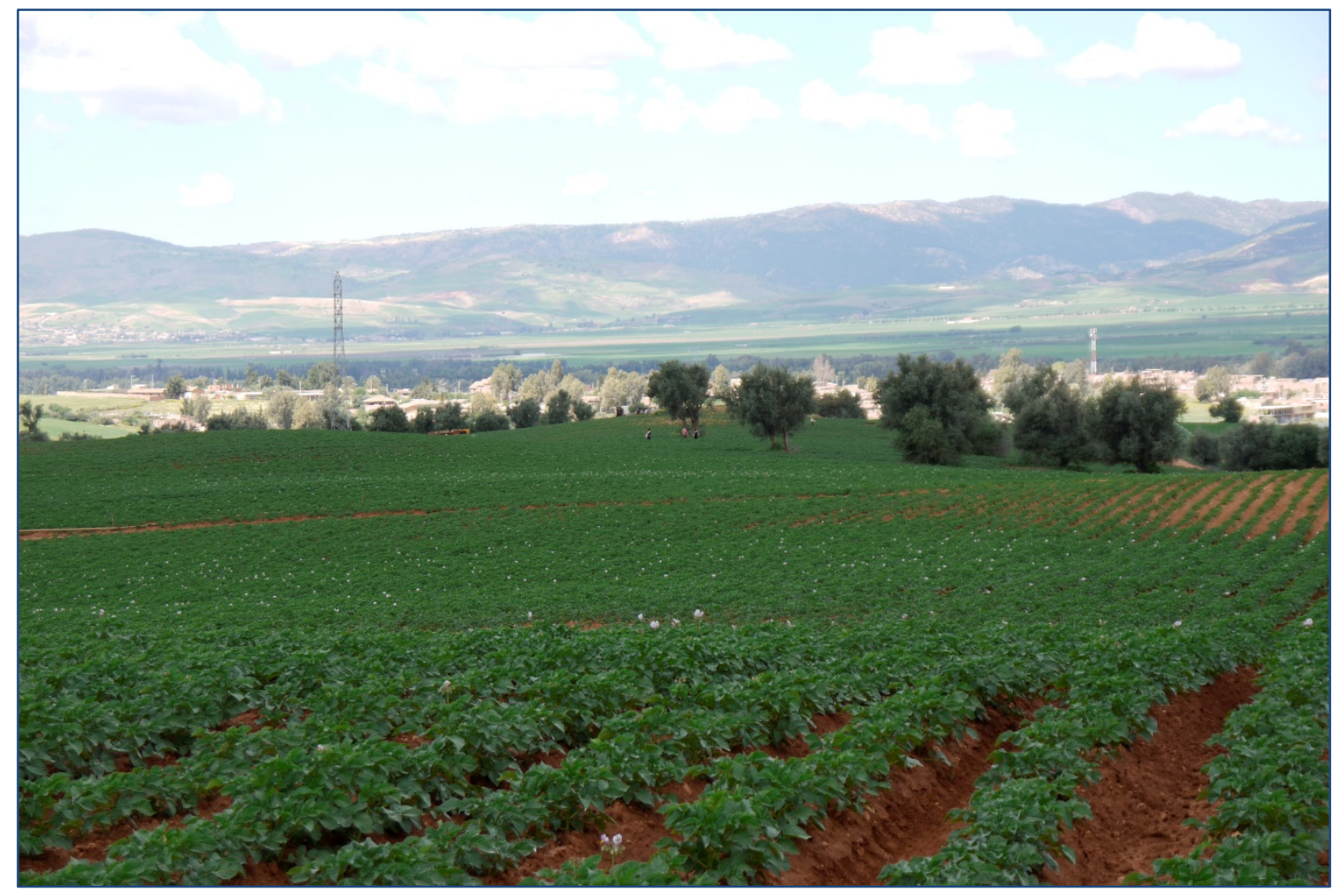




\section{Tunisia profile}

Officially the country is called Republic of Tunisia, a sovereign state in Northwest Africa, covering 165,000 square kilometres ( $4 x$ the Netherlands). It is bordered by Algeria to the west and southwest, Libya to the southeast, and the Mediterranean Sea to the north and east. Tunisia's population was estimated to be just under 11.660 million in 2018. Tunisia's name is derived from its capital city, Tunis, which is located on its northeast coast.

\section{$2.1 \quad$ Geography}

Tunisia contains the eastern end of the Atlas Mountains and the northern reaches of the Sahara Desert. Much of the rest of the country's land is fertile soil. Its 1,300 kilometres of coastline includes the African conjunction of the western and eastern parts of the Mediterranean Basin and, by means of the Sicilian Strait and Sardinian Channel, features the African mainland's second and third nearest points to Europe after Gibraltar. Tunisia is divided in 24 governates of which Tataouine and Kebili in the Sahara region are by far the largest, but very low in population. In that context Sfax and Tunis are the major governates (Figure 1).

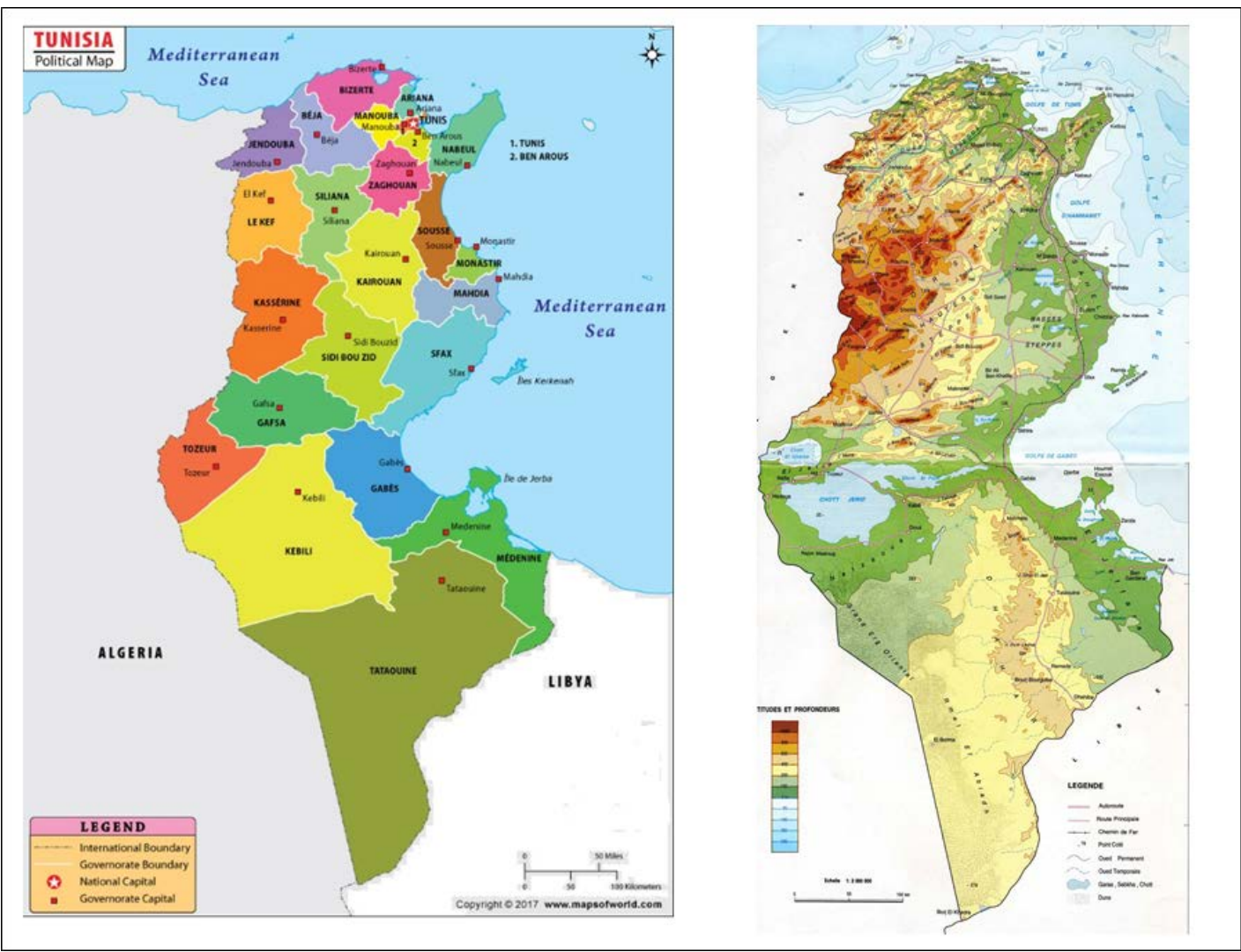

Figure 1: political and physical map of Tunisia ${ }^{1}$

\subsection{Population}

In Tunisia the current population size is estimated at $11,659,174$ people 2 . The annual growth rate since 2010 is about $1.1 \%$. The growth on the national level between 2010 and 2017 was $8.3 \%{ }^{3}$, 2017), but there are big differences between governorates. The governorates with the largest population have the largest growth (Table 1).

\footnotetext{
${ }^{1}$ https://www.cityzeum.com/carte-touristique/tunisie, and https://www.mapsland.com/africa/tunisia/large-detailedphysical-map-of-tunisia, both viewed 7-5-2018

2 http://www.worldometers.info/world-population/tunisia-population/ , viewed 19-4-2018

${ }^{3}$ Statistics, N.I.o., Tunisia in numbers. 2014: p. 56
} 


\begin{tabular}{|l|c|c|}
\hline Governorate & 2017 & 2010-2017 index \\
\hline Tunis & 1070 & 104 \\
\hline Sfax & 995 & 109 \\
\hline Nabeul & 832 & 111 \\
\hline Sousse & 717 & 115 \\
\hline Ben Arous & 678 & 117 \\
\hline Ariana & 629 & 123 \\
\hline
\end{tabular}

Table 1: population $(x 1000)$ for 6 governorates with the highest population and index growth since 2010

Except for Tunis the governorate population has grown faster than the national average (Figure 2). This confirms the urbanization rate of $1.28 \%{ }^{4}$ (further information in this paragraph is retrieved from the same website). The current level of urbanization in Tunisia is quite high: $67.3 \%$, number 3 in Africa after Libya and Algeria ${ }^{5}$.

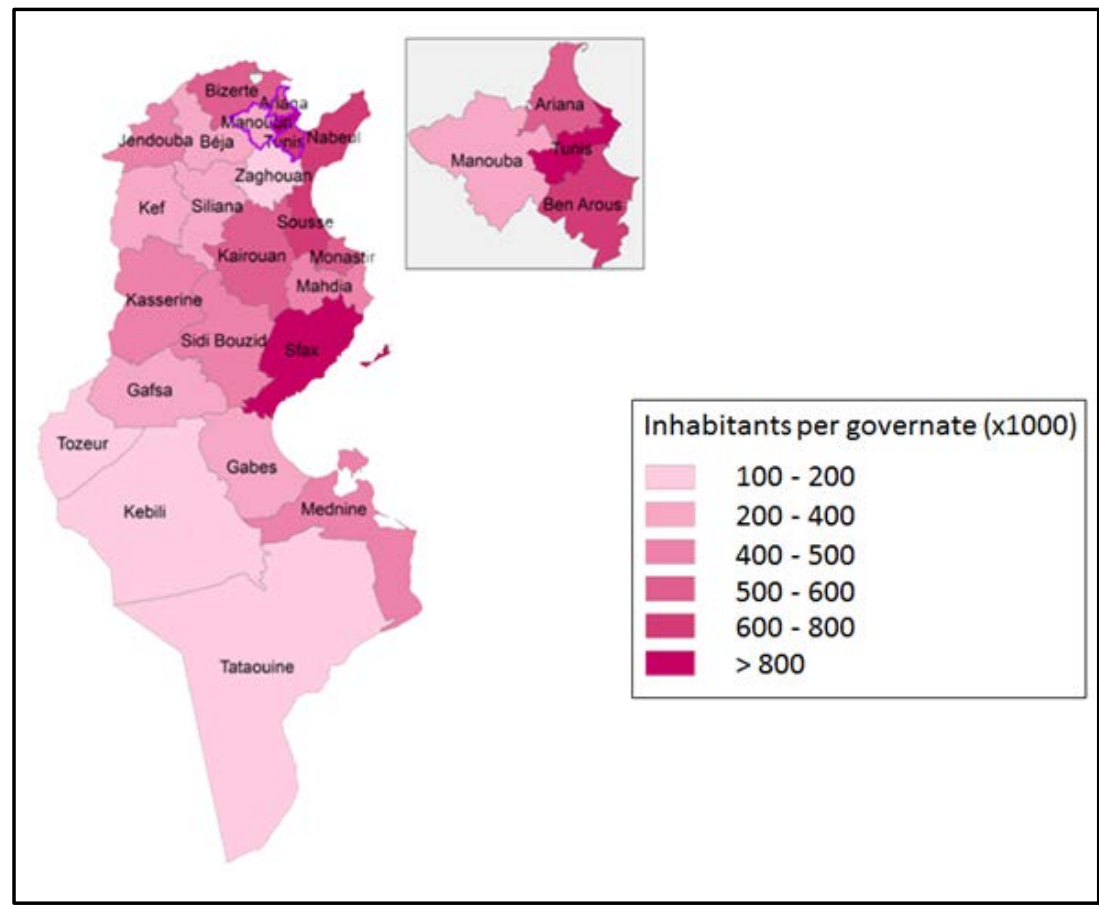

Figure 2: distribution of population per governorate ${ }^{3}$

The rural areas are typically in the South, Tozeur, Kebili and Tataouine. The North and North West of Tunisia are average with respect to amount of population.

About $98 \%$ of the population is Arab, 1\% European, 1\% rest; and $99.1 \%$ of the religion is Muslim. The commercial languages are Arab and French, whereas Berber is used in a more social context.

\subsection{Economy}

Contrary to many African countries Tunisia already managed to have a market-driven economy, which mainly depends on natural resources. It is ranging from agriculture, mining, manufacturing, and petroleum products, to tourism. The agricultural sector accounts for $11.6 \%$ of the GDP, industry $25.7 \%$, and services $62.8 \%$. About $16 \%$ of the Tunisian workforce is engaged in agriculture ${ }^{6}$. The industrial sector is mainly made up of clothing and footwear manufacturing, production of car parts, and electric machinery. Services are very much related to government departments (African

\footnotetext{
${ }^{4}$ https://www.indexmundi.com/tunisia/demographics_profile.html, viewed 19-4-2018

${ }^{5}$ https://en.wikipedia.org/wiki/Urbanization_by_country , viewed 19-4-2018

${ }^{6}$ https://www.export.gov/article? id=Tunisia-Agricultural-Sector, viewed 29-4-1018
} 
Development Bank, 2017). The GDP per capita in Tunisia equals 3496 US\$ in 2017 resulting in about rank 140 worldwide ${ }^{7}$. Although Tunisia managed an average $5 \%$ growth over the last decade it continues to suffer from a high unemployment especially among youth ${ }^{8}$.

Exports are 13.57 billion US\$, imports 18.37 billion US\$. Key exports now include textiles and apparel, food products (like dates, olive oil and tomatoes), petroleum products, chemicals, and phosphates. Imports include electrical devices, machinery, mineral fuels, oils, vehicles, plastics, cereals and cotton. The European Union is Tunisia's first trading partner, currently accounting for $72.5 \%$ of Tunisian imports and $75 \%$ of Tunisian exports. The country is one of the European Union's most established trading partners in the Mediterranean region and ranks as the EU's 30th largest trading partner. Tunisia was the first Mediterranean country to sign an Association Agreement with the European Union, in July 1995, although even before the date of entry came into force, Tunisia started dismantling tariffs on bilateral EU trade. Tunisia finalized the tariffs dismantling for industrial products in 2008 and therefore was the first Mediterranean country to enter in a free trade area with EU.

In agriculture the potato sector has a significant contribution to the production value (Table 2; ZEF et al., 2017):

\begin{tabular}{|l|c|l|c|}
\hline Product & $\begin{array}{l}\text { Production } \\
\text { quantity }(\%)\end{array}$ & Product & $\begin{array}{c}\text { Production } \\
\text { value* (\%) }\end{array}$ \\
\hline Wheat & 16.6 & Olives & 14.2 \\
\hline Tomatoes & 14.2 & Milk, whole fresh cow & 10.8 \\
\hline Olives & 10.1 & Wheat & 10.5 \\
\hline Barley & 7.4 & Meat, chicken & 6.7 \\
\hline Watermelons & 5.7 & Meat indigenous, chicken & 6.7 \\
\hline Chilies and peppers, green & 4.7 & Dates & 6.3 \\
\hline Potatoes & 4.6 & Tomatoes & 4.8 \\
\hline Onions, shallots, green & 3.1 & Almonds, with shell & 4.4 \\
\hline Carrots and turnips & 2.7 & Eggs, hen, in shell & 3.8 \\
\hline Dates & 2.4 & Chilies and peppers, green & 3.4 \\
\hline
\end{tabular}

Table 2: average agricultural production quantity and value 2012-2014 (FAOSTAT); * Gross Production Value (constant 2004-2006 million USD), data: average 2011-2013 (FAOSTAT)

Reference average production volume: wheat $(2012-2014)=1,337$ kton

Reference average GPV (constant 2004-2006 million USD): olives (2011-2013) = 563 million USD

The most important agri-food exports are olive oil, dates, seafood, vegetable oils and fats and cereals and derivatives (Tabet, M., et al, 2013). With respect to import the main products are wheat, maize, soybeans, barley and refined sugar (ZEF et al., 2017). These products are relevant to livestock feed and to show the level of self-sufficiency in Tunisia the import data are presented in Table 3:

\begin{tabular}{|l|c|c|c|}
\hline Product & Import quantity (ktons) & Production (ktons) & Self-sufficiency \\
\hline Wheat & 1,486 & 1,337 & $<50 \%$ \\
\hline Maize & 868 & Not in top 10 & $<20 \% *$ \\
\hline Soybeans & 467 & Not in top 10 & $<30 \% *$ \\
\hline Barley & 821 & 596 & $<45 \%$ \\
\hline
\end{tabular}

Table 3: indication of self-sufficiency on feed products. *Dates in Table 2 correspond to 193 ktons.

Remark: Tunisian export of these four products is negligible ${ }^{9}$

The Foreign Direct Investment (FDI) in Tunisia in agriculture is $1 \%$, whereas $52 \%$ is invested in the manufacturing industry (Soltane, B.B., 2017). One of the reasons is that public land may be leased by the government to private farmers or managed directly by the Ministry of Agriculture. Foreigners cannot own agricultural land but may obtain long-term leases. Agriculture is also not the most

\footnotetext{
${ }^{7}$ http://www.imf.org/external/datamapper/NGDPDPC@WEO/OEMDC/ADVEC/WEOWORLD/TUN , viewed 24-4-2018

8 https://en.wikipedia.org/wiki/Tunisia\#Economy, viewed 24-4-2018

${ }^{9}$ FAOSTAT, viewed 14-5-2018
} 
important business in Tunisia as can be derived from the fact that approximately $16 \%$ of the country's workforce is engaged in the agricultural sector, and agriculture contributes about $12 \%$ to the country's $\mathrm{GDP}^{10}$. In 2011, after the Arab Spring, the economy slumped but then recovered and the GDP is increasing (Figure 3).

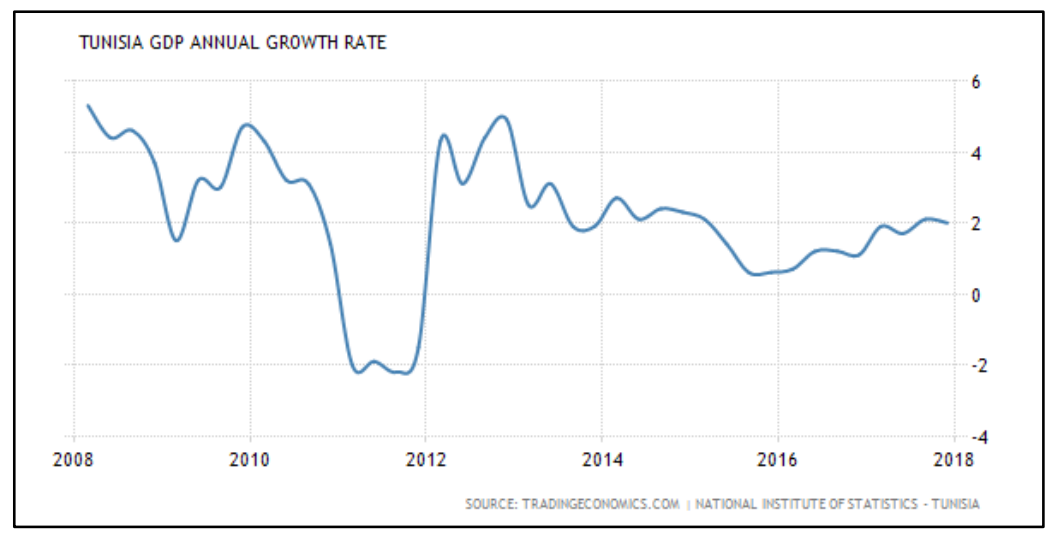

Figure 3: GDP growth in Tunisia

In 2015 , the food processing sector accounted for over 1,000 enterprises each employing 10 people or more, $20 \%$ of them producing solely for export. The production value of this sector is around $\$ 5$ billion annually and is continuously growing due to improved household purchasing power and changes in eating habits towards consumption of processed products versus fresh ones.

\section{$2.4 \quad$ Climate}

Tunisia covers about 165,000 square kilometers. This total area consists of $30 \%$ arable land, $27 \%$ pasture and forests, and approximately 43\% agriculturally unusable land (Thabet B., et al., 1994). With respect to the climate, Tunisia can be divided in 5 dynamic climate zones: 1. humid, 2.

subhumid, 3. semiarid, 4. arid and 5. desert (You, H. et al., 2016). The climate zones are shown in Figure 4 .

Rainfall is a major, though variable, factor, ranging from an average of less than 100 millimeters a year in the south, to over 1000 millimeters a year in the extreme north of the country. The estimated rainfall in Tunisia amounts to $36,000 \mathrm{Mm}^{3} /$ year, corresponding to an average rainfall height of $220 \mathrm{~mm} /$ year (Chahed J. et al., 2010). About $80 \%$ of the rainfall is concentrated between October and March. The annual potential evapotranspiration ranges from $1200 \mathrm{~mm}$ in the north to $1800 \mathrm{~mm}$ in the south (source: Aquastat Tunisia profile). In the northern part, the topography is more and more sloped, leaving relatively little cultivable land in areas of relatively high rainfall. A classification of the annual rainfall in the different bioclimatic zones is shown in Table 4.

\begin{tabular}{|l|l|}
\hline Bioclimatic zone & Annual rainfall (mm) \\
\hline Humid & $800-1200$ \\
\hline Subhumid & $600-800$ \\
\hline Semiarid & $400-600$ \\
\hline Arid & $100-400$ \\
\hline Desert (Saharan) & $20-100$ \\
\hline
\end{tabular}

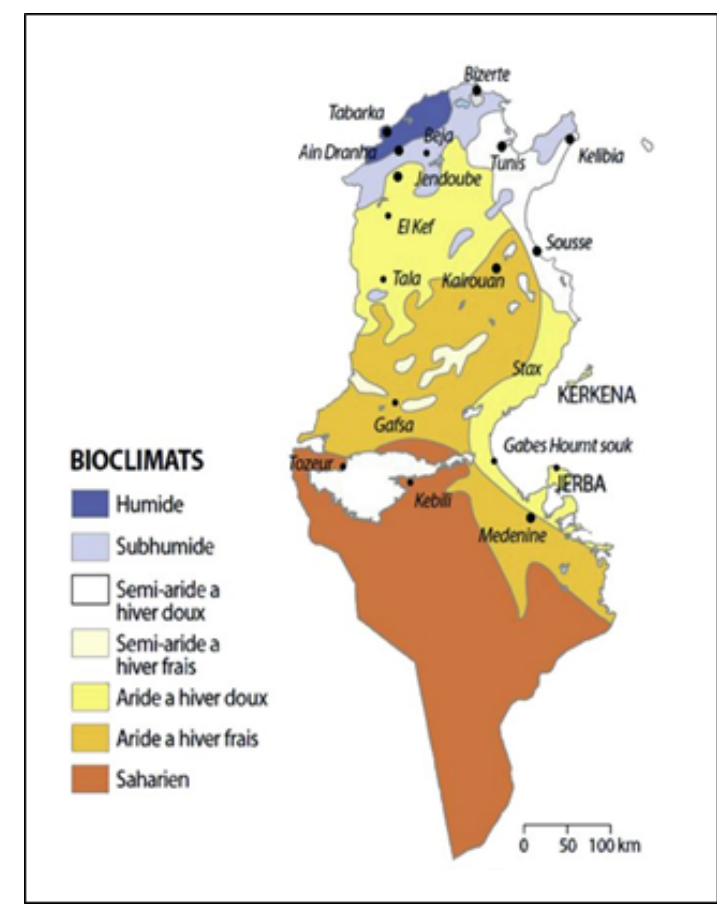

Figure 4: climatic zones in Tunisia (Source: You et al., 2016)

Table 4: Annual rainfall in the different bioclimatic zones [7]

\footnotetext{
${ }^{10}$ https: // www.export.gov/article?id=Tunisia-Agricultural-Sector, viewed, 24-4-2018
} 
The potential conventional water resources are estimated at 4.8 million $\mathrm{m}^{3}$ per year, of which $2.7 \mathrm{Mm}^{3}$ is surface water and $2.1 \mathrm{Mm}^{3}$ is groundwater (sources: ONAGRI Agricultural portal Tunisia; Hamza, 2006; Gaaloul, 2008, Besbes et al, 2008; Jacobs \& Van 't Klooster, 2012). The northern basins in Tunisia provide the largest contribution of surface water resources of the country. The major basins in the North are the Medjerdah Basin, in the extreme North, and the Oued Miliane.

It is expected that after 2020, an imbalance will appear between the conventional water resources regularized and the total water demand of the country (Lebdi, 2009; PAPS EAU 2010). By 2030, demand is likely to exceed the conventional resources available. It is expected that climate change will result in a significant reduction in rainfall and an increase in the frequency of droughts (Besbes et al 2010). However, the extent and the accuracy remain imprecise.

Temperature and wind are no less variable, frequently causing serious damage to agricultural crops. In J uly and August, temperatures can exceed $40{ }^{\circ} \mathrm{C}$ when the tropical continental air mass of the desert reaches the whole Tunisia. Winters are mild with temperatures rarely exceeding $20^{\circ} \mathrm{C}$ (exception is the south-west of the country). The terrain in the north is mountainous, which, moving south, gives way to a hot, dry central plain. In the south, daytime temperatures consistently turn around $45^{\circ} \mathrm{C}$, while can be cold in the desert (Figure 5).

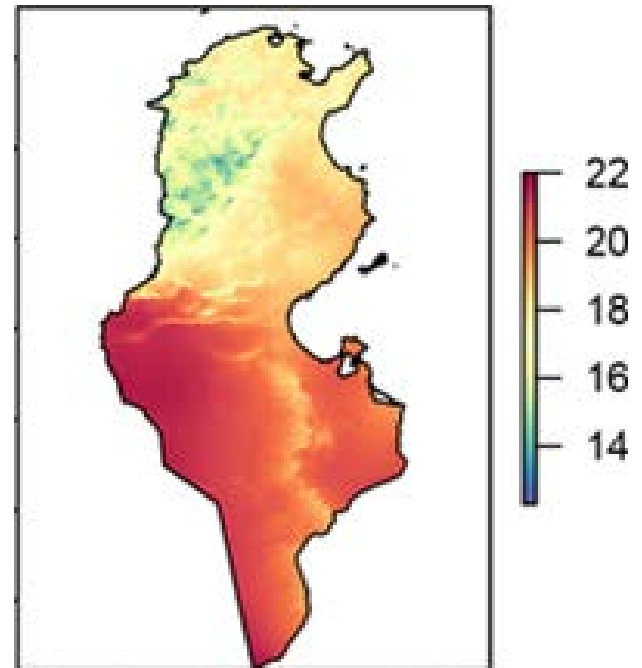

Figure 5: annual mean temperature map of Tunisia (Source: Ben Abdelkrim et al., 2017).
Tunisia's Mediterranean climate with mild winter and sunny springs are suitable for most vegetables. Vegetable crops cover an area of 150,000 ha, mostly tomato (25,000 ha), potato (23,000 ha), melon, pepper and onions (Jacobs, C. et al., 2012). The most likely consequences of Climate Change for Tunisia will be a reduction in rainfall and an increase in the frequency of droughts (Besbes., M., et al., 2010). However, the extent and the accuracy remain imprecise. Apart from an increase in drought, salinity is also a problem in Tunisia. Generally, surface water has a low salinity, but groundwater is badly affected with $84 \%$ of all groundwater resources having salinity levels of more than $1.5 \mathrm{~g} / \mathrm{l}$ and $30 \%$ of the shallow aquifers more than $4.0 \mathrm{~g} / \mathrm{l}$ (Gaaloul, 2008).

\subsection{Policy trends in food and agriculture}

Tunisia is an upper-middle income country and has been experiencing strong economic growth since 2000. This growth was interrupted during the mass protests and eventual ousting of the Government in 2011. High unemployment was one of the triggers for the 2011 "revolution" and continues to be a source of social unrest. Successive governments have been trying to address the problems of unemployment and social exclusion. In October 2012, new employment schemes were designed, The full implementation of these programmes have faced considerable delays, due to limited capacities at the Ministry of Employment and ANETI (Agence nationale pour l'emploi et le travail indépendant). But by 2014, a new constitution was adopted; parliamentary and presidential elections were held; and a new government was formed, with an agenda of tough economic reforms to boost economic growth and job creation (FAO, 2017).

Since 2007, the Government developed a number of plans and strategies to address agriculture and food and nutrition security, focussing on economic growth and job creation. In TUNISIA 2020, the five-year plan launched in 2016, the government aims at an annual growth rate of $4 \%$ by 2020 and to have a significant impact on the agricultural sector and rural development (FAO, 2017), by:

a. Improvement of Tunisian farmers income and modernization of farms (20 000 in 5 years),

b. Contribution of the agricultural GPD (+11 percent), 
c. Strengthening agricultural production,

d. Creating jobs in rural areas, and

e. Improving national food security.

The Tunisian trade policy is characterized by market liberalization and commitment to higher integration in the global economy by: Adopting new laws to open markets, lowering import tariffs and Formulating a new tax strategy. The main challenge for the Government is sustainable economic growth. As far as agriculture sector is concerned, the growth will be achieved through 1) linking social protection with employment programmes; 2) reform of subsidies; 3) operationalize market reforms policies. In the area of sustainable trade and investment, the Netherlands Embassy mentions in her 'Country Strategy 2018 -2023 Tunisia' possibilities of five focus sectors with notable potential in Tunisia:

1. Agri- and horticulture;

2. Water;

3. Waste management;

4. Logistics;

5. Maritime sector.

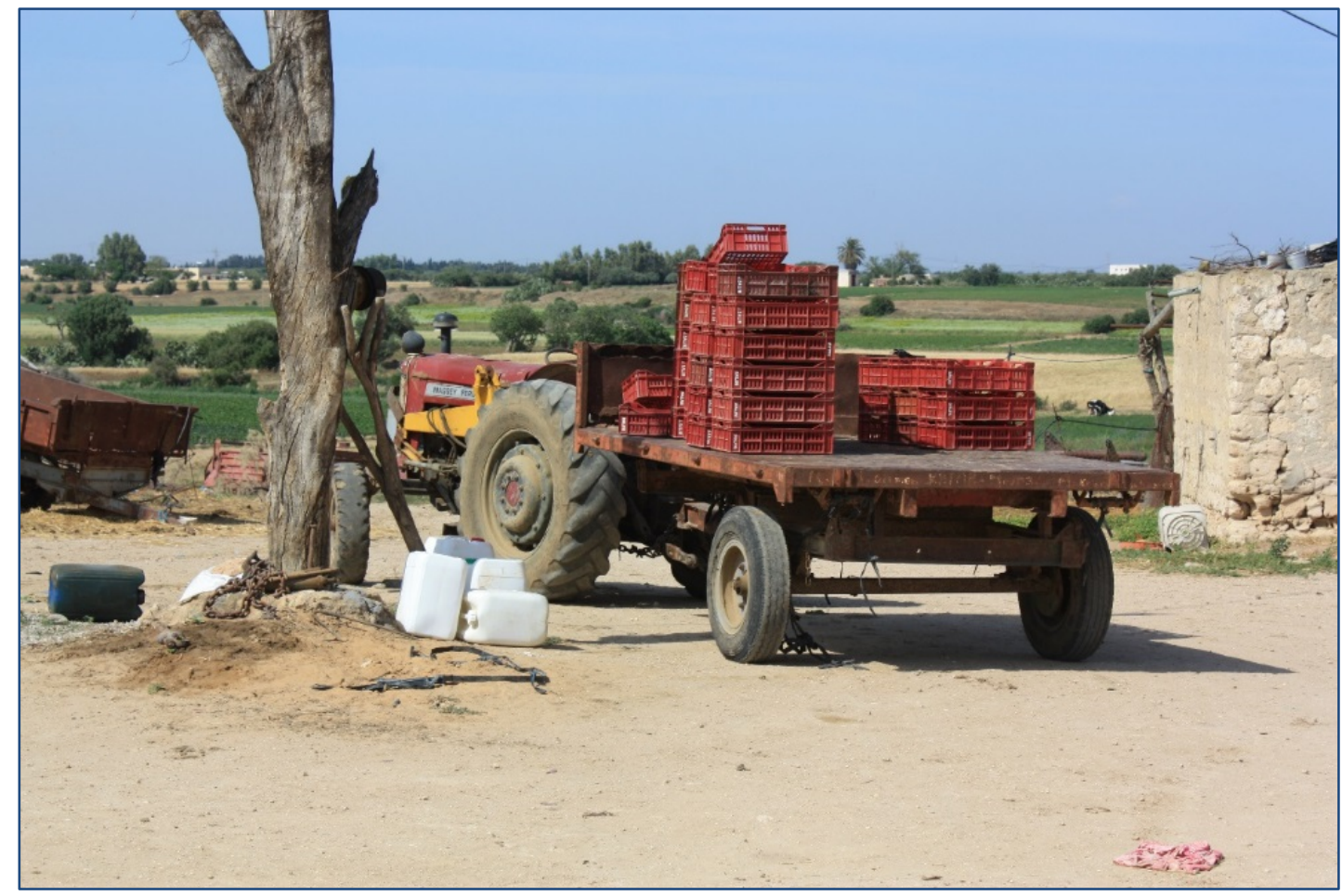




\section{Potato sector}

In Tunisia, potatoes have a significant contribution to the production value. Approximately 27,000 hectares ( $17 \%$ of the country's cultivated land) are used for potato production and produces yearly on average 370,000 tons of potatoes. Thus, the need for seed potatoes is high, making Tunisia a net importer of seed potatoes from Europe.

The main focus of the potato chain is on primary production. Most of the produced potatoes are sold to the consumer, while processing of potatoes hardly occurs. Tunisians consume between 22,000 and 25,000 tonnes of potatoes a month. However, throughout the year supply and demand for ware potatoes are not well balanced. When supply exceeds the demand, potatoes are exported, mainly to Libya. When demand exceeds supply, the government starts to import potatoes.

The Tunisian potato supply chain is depicted in Figure 6.

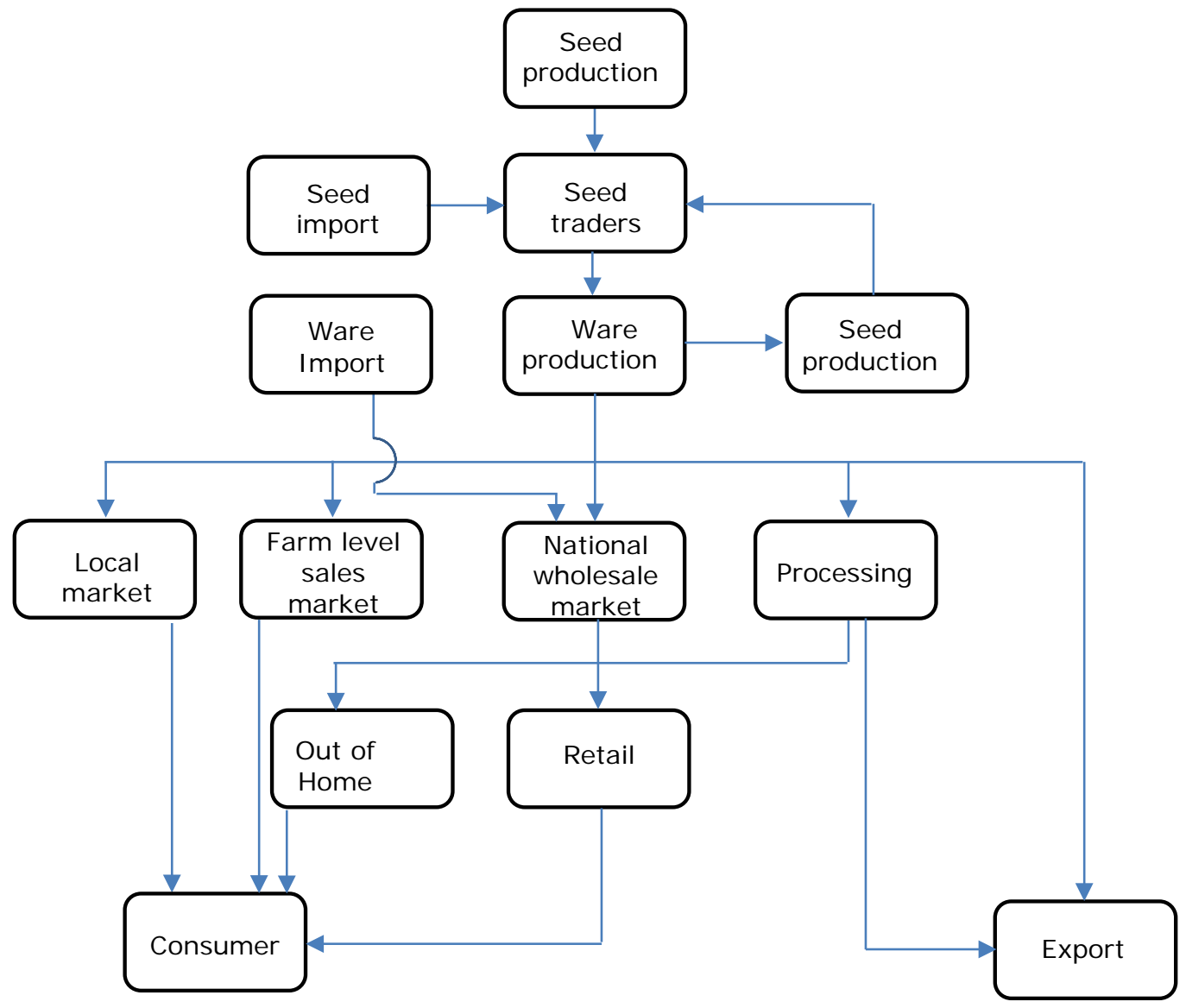

Figure 6. Potato value chain

\subsection{Potato production and sale}

The main production areas in Tunisia are shown in Figure $7^{11}$. Currently, farming with monocultures and specialising per region are becoming more popular. Tunisia has four potato seasons:

1. $1^{\text {st }}$ season: January - June

2. $2^{\text {nd }}$ season: September - January

3. Extra season: October - February

4. Small scale: December - April

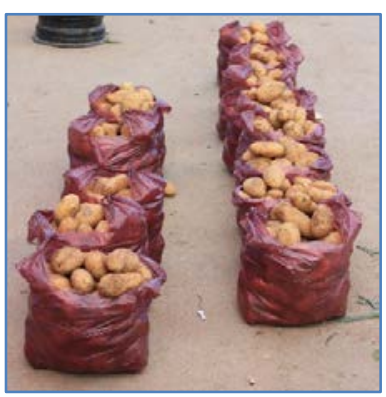

\footnotetext{
11 http://www.freshplaza.com/article/106730/Tunisian-potato-production, (accessed 09-04-2018)
} 
The first and second season can be considered as main seasons regarding volumes. From March through July potatoes are harvested continuously, as well as in December and January (Horton et al., 1986). Some characteristics of these two production seasons for the period 2012 - 2014 are shown in Table $6^{12}$. Generally, the $1^{\text {st }}$ season has the highest production.

The fields of most farmers are small: $40 \%$ of the plots $<1$ ha, $50 \%$ of the farmers have $1-1,5$ ha of potato, while only $10 \%$ of the producers plant more than 3-4 ha.

In these three farming systems the needs are different, but the focus of the government is mainly on the smallholders as they present the majority of the farmers.

Potatoes are also planted in the "irrigated perimeters" of the interior such as Jendouba and Beja (Horton et al., 1986). The level and timing of irrigation depends on location, weather during any given year and soil characteristics. Even where water is plentiful, high infiltration rates in sandy soils can cause droughts. Some of the interior mountains receive relatively high rainfall, up to 1500 $\mathrm{mm}$ in the Kroumirie Mountains. Heavy rains can be equally problematic, causing waterlogging in clayey soils or soil degradation (Ghodbane, 1980).

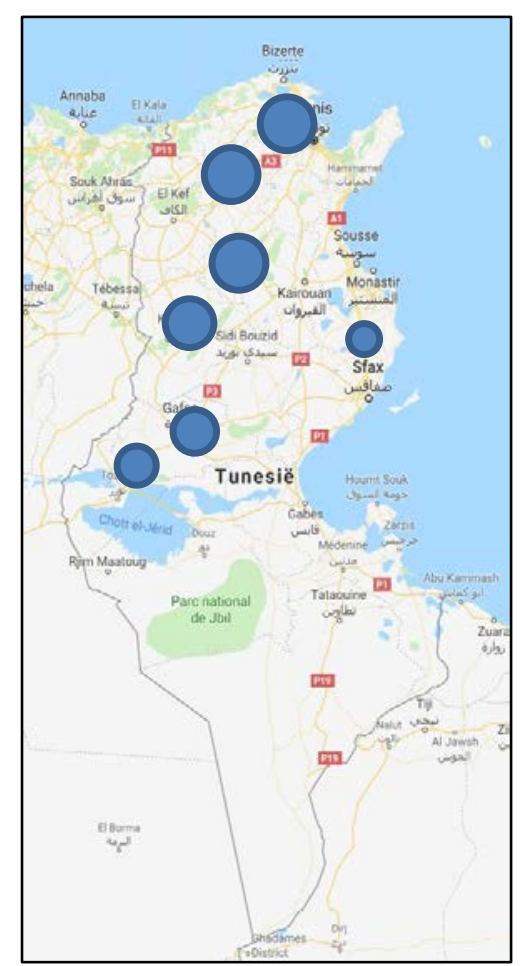

Figure 7. Production areas of potato in Tunisia

About one month prior to planting, fields are spread with farmyard manure. Inorganic fertilizers are also widely used before and after planting. Main diseases in the potato growth are (Ghodbane, 1980): Late blight (Phytophthora infestans) and early blight (Alternaria solani), particularly during the main season; fungal diseases like black scurf (Rhizoctonia solani) and verticillium wilt (Ghodbane, 1980) and viral diseases, like Leaf Roll Virus (PLRV). Damage by tuber moths is widespread during the main season both in the field and during storage. To tackle these diseases, Tunisia imports a huge amount of biocides. In 2016, the country imported biocides at a cost of about 54 million dollars ${ }^{13}$.

Half of all potatoes are harvested manually. Average yearly production is 18-20 ton/ha. However, variations between farms are high: small farmers only produce yearly 12-15 ton/ha, or in good years up to 19 ton/ha. Only in exceptional cases, yields of 60 ton/ha are achieved. Some farmers grow their own seed, especially in autumn with relatively low yields and small tubers, but high tuber quality. These tubers are stored in a controlled environment. However, the local seed production only includes 4000 ton, while 25.000 ton is imported. Table 7 shows the import of seed potatoes from different countries in the period $2013-2016^{14}$. Most seed potatoes are imported from NW Europe.

\begin{tabular}{|l|c|c|c|c|c|c|}
\hline \multirow{2}{*}{ Production Season } & \multicolumn{3}{|c|}{$1^{\text {st }}$ season } & \multicolumn{3}{c|}{ 2 $^{\text {nd }}$ season } \\
\hline Year & 2012 & 2013 & 2014 & 2012 & 2013 & 2014 \\
\hline Area (1000 ha) & n.a. & n.a. & n.a. & 11 & 10.35 & 11.9 \\
\hline Production (1000 tonnes) & 180 & 175 & 185 & 115 & 130 & 145 \\
\hline Main production regions & \multicolumn{3}{|l|}{ Kasserine- Kairouan - Cap Bon } & $\begin{array}{c}\text { Cap Bon - J endouba-Gafsa- Sidi } \\
\text { Bouzid- Kasserine- Kairouan }\end{array}$ \\
\hline Main varieties & \multicolumn{4}{l|}{ Mainly Spunta } & \multicolumn{2}{l|}{ Spunta, Nicola } \\
\hline Destination & Local market, export &
\end{tabular}

Table 6. Characteristics of the potato growth in the $1^{\text {st }}$ and $2^{\text {nd }}$ season for the period $2012-2014$.

The provision of physiologically mature seed at the right time for planting is difficult. Both for the local produced seed as for the imported seeds, storage is necessary. As storage circumstances are not

\footnotetext{
${ }^{12} \mathrm{http}$ // www.gil.com.tn/fr/product?label=pomme-de-terre_3 (data from 2016; website accessed on 02-05-2018)

${ }^{13}$ Source: UNcomtrade

${ }^{14}$ Source: UNcomtrade
} 
always appropriate, losses of seed potatoes by rot or dehydration may occur (up to $20 \%$, according to the interviewee from GIL).

\begin{tabular}{|l|c|c|c|c|}
\hline Country & 2013 & 2014 & 2015 & 2016 \\
\hline France & 16524 & 14256 & 13430 & 17622 \\
\hline Netherlands & 9507 & 8057 & 6598 & 6601 \\
\hline Belgium & 1028 & 235 & & 144 \\
\hline Luxembourg & 521 & 239 & 50 & \\
\hline Denmark & 545 & 150 & & 10 \\
\hline Italy & 10 & & & \\
\hline Germany & 1 & 3 & & 24377 \\
\hline $\begin{array}{l}\text { Areas } \\
\text { (not elsewhere } \\
\text { specified) }\end{array}$ & & 527 & & \\
\hline $\begin{array}{l}\text { Total } \\
\text { Total }\end{array}$ & 28135 & 23466 & 20078 & \\
\hline
\end{tabular}

Table 7. Amount of imported seed potatoes (ton) from different countries in the period 2013 - 2016.

Officially 86 cultivars are grown, from which 51 varieties are reported in the official catalogue from the Ministry ${ }^{15}$. But the main cultivars are Spunta, Bellini and Nicola as they have best yield in all seasons. Moreover, according to one of the interviewees, a diversity in cultivars is not appealing for the Tunisian consumer, as the consumer only looks for the cheapest potato.

Potatoes are mainly packed in Big Bags though it is possible to place the product in crates, nets or cardboard boxes depending on the needs of the client. However, transport is a sometimes problem as many roads are very bad, especially in the Northwest. There are different ways in which the potatoes are sold: 1) at farm level, 2) at the local market, 3) to a broker or retailer and 4) illegal or to speculators ${ }^{16}$, estimating the last category be a relatively large category.

Storage of ware potatoes becomes important between July and December. Storage in a controlled environment is very costly and therefore mainly affordable by big farmers, while small holders can hardly afford the purchase of this equipment. Current available storage equipment only amounts to 40.000 ton/year, while 70.000 ton/year is inadequately stored (f.e. under a tree) causing losses until about $20 \%$. Due to these inadequate stock conditions, supply and demand are not in equilibrium. During periods of surplus, Tunisia starts exporting potatoes. However, as soon as shortages of ware potatoes occur during those months, the government starts to import potatoes. Table 8 shows respectively import from and export to different countries from $2013-2016^{17}$. It can be seen, that Tunisia both imported from and exported to countries like France, The Netherlands, Italy, Germany and Libya.

The processing of potatoes is not well developed. No

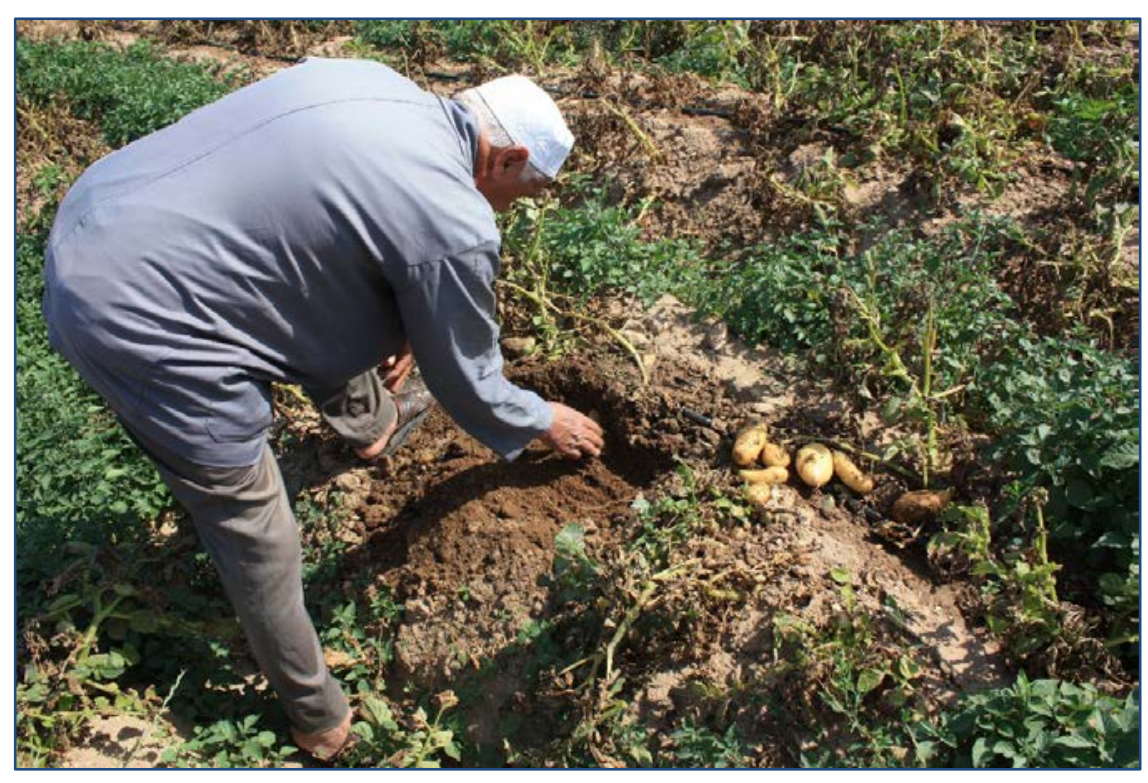

\footnotetext{
${ }^{15} \mathrm{http}$ // www. freshplaza.com/article/106730/Tunisian-potato-production, (accessed 09-04-2018)

${ }^{16} \mathrm{https}$ ///africanmanager.com/13_nabeul-un-speculateur-avec-planque-170-t-de-pommes-de-terre/ http://kapitalis.com/tunisie/2017/11/16/tunisie-le-kilo-de-pommes-de-terre-a-1-180-dinars/

${ }^{17}$ Source: UNcomtrade
} 
processing into French fries occurs. Spunta is not appropriate for processing into French fries, while cultivars suitable for French fries are only show adequate yields part of the year, which is considered to be not attractive for farmers due to a low cost-effectiveness. Some private individuals produce French fries by peeling and cutting the potatoes manually and supply it to restaurants, which can be considered to be unhygienic and often of bad quality.

Chips are locally produced in Tunis (Mad Chips), but potatoes are not year-round available. Mad Chips only runs a few months per year, has a low production and its quality is not highly rated.

Tunisia has 80 supermarkets (Carrefour) and 2 hypermarkets. Supermarkets and hypermarkets have no storage facilities and buy daily fresh potatoes. The hypermarket purchases 4 ton fresh potatoes every day (i.e. 1200 ton/year) at the farm or from the retail. No collection centres exist for potatoes. The longest distance of the daily transport is about $250 \mathrm{~km}$ in the North and about $350 \mathrm{~km}$ in the South. During periods of surplus of potatoes, Carrefour is asked by the Ministry of Trade to sell potatoes for low prices to prevent rot.

\begin{tabular}{|l|c|c|c|c|c|c|c|c|}
\hline \multirow{2}{*}{ Country } & \multicolumn{2}{|c|}{2013} & \multicolumn{2}{c|}{2014} & \multicolumn{2}{c|}{2015} & \multicolumn{2}{c|}{2016} \\
\cline { 2 - 10 } & Export & Import & Export & Import & Export & Import & Export & Import \\
\hline France & 1476 & 16524 & 539 & 14280 & 6 & 14099 & 16 & 17622 \\
\hline Netherlands & 47 & 9507 & 26 & 8057 & & 6790 & & 6601 \\
\hline Turkey & & 5152 & & & & & & \\
\hline Belgium & & 1028 & & 235 & & & & 240 \\
\hline Denmark & & 545 & & 150 & & 899 & & \\
\hline Luxembourg & & 521 & & 239 & & 50 & & \\
\hline Italy & 5700 & 10 & 2390 & & 235 & & 468 & 10 \\
\hline Germany & 1658 & 1 & 1636 & 3 & & & & \\
\hline Libya & 396 & & 5060 & 260 & 173 & 10666 & 2343 & 15025 \\
\hline Other Areas & 3077 & 75 & 5173 & 527 & 246 & 7391 & 465 & 451 \\
\hline Total & 12354 & 33362 & 14822 & 23750 & 660 & 39895 & 3292 & 39949 \\
\hline
\end{tabular}

Table 8. Import and export data of ware potatoes (ton/year) to different countries in the period 2013 $-2016$.

\subsection{Potato sector in social context}

In Tunisia, some farmers in the potato sector, are growing potatoes by habit and to have a job. But 'to be a farmer' is no official occupation with a certain status or required educational level. Only few farmers $(5 \%)$ are organized and member of a labour union or active in some network with transparent logistics. Farmers are reluctant to organize, considering it as top down control, too much entanglement of political interests and thus no proper way to be heard. As a result, knowledge transfer between farmers is slow. Thus, mechanisation and innovation of the sector are low. For young people (around $55 \%$ of the Tunisian population < 35 year) the sector has insufficient perspective. Although young people attend agricultural schools, many of the students are not really interested in farming and leave the rural areas after obtaining a certificate. As a result, $60 \%$ of the farmers $>60$ years old, while lacking knowhow, mechanisation and enough labour to manage the farm. Governmental extension services try to better involve the private sector and to stimulate publicprivate partnerships, but farmers are still not willing to pay for services or training. A new paradigm on payment for services is needed.

Availability of finances is a big problem as no subsidies are available. The potato sector has no official, governmental registration apparatus, causing non-transparency of ownerships, plot size of farmers, level of education and production data. Without any kind of registration, identification or documentation on property farmers have no access to finance. It also complicates the establishment of individual partnerships with EU countries or to improve the export to EU countries. Apart from that, it even offers space for illegal sale and mutual distrust. 


\section{$4 \quad$ The pricing system}

The market price of potato does not reflect the production costs, but is determined by the government based on an agreement between the Ministry of Trade (Commerce and Traditional industries?) and the Ministry of Agriculture. Tunisia has a big inflation $(23,7 \%)$ and as soon as speculators start storing potatoes, prices are driven up and create an unfavourable export position for Tunisia with Europe. Storage of potatoes creates a shortage and triggers the government to intervene by starting import again. The imbalance between supply and demand and the resulting alternation between import and export causes an unpredictable fluctuation in price. As an example, Carrefour currently sells potatoes for 600 millimes/kg ( $€ 0,20)$, last year for 1 Dinar/kg $(\sim € 0,30)$. This fluctuation makes planning and the development of long term strategies impossible.

In general, the price the farmer receives, is too low to cover the costs. Due to different intermediates (broker, retailers, speculator) in the chain, all skimming part of the income, less money is left for the farmer. Therefore, the farmer often is forced to combine potato production with other agricultural activities. As market prices are not reflecting the production costs, the farmer has no clear incentives to increase potato yield. A lowering of costs is not feasible for small famers since they are not organised, have a low level of mechanisation and no clear idea how innovation will affect their returns on investment and economic benefits.

Although no French fries are produced on an industrial scale, there is currently no incentive to start this activity, as the price of imported French fries is low due to covenants with other countries.

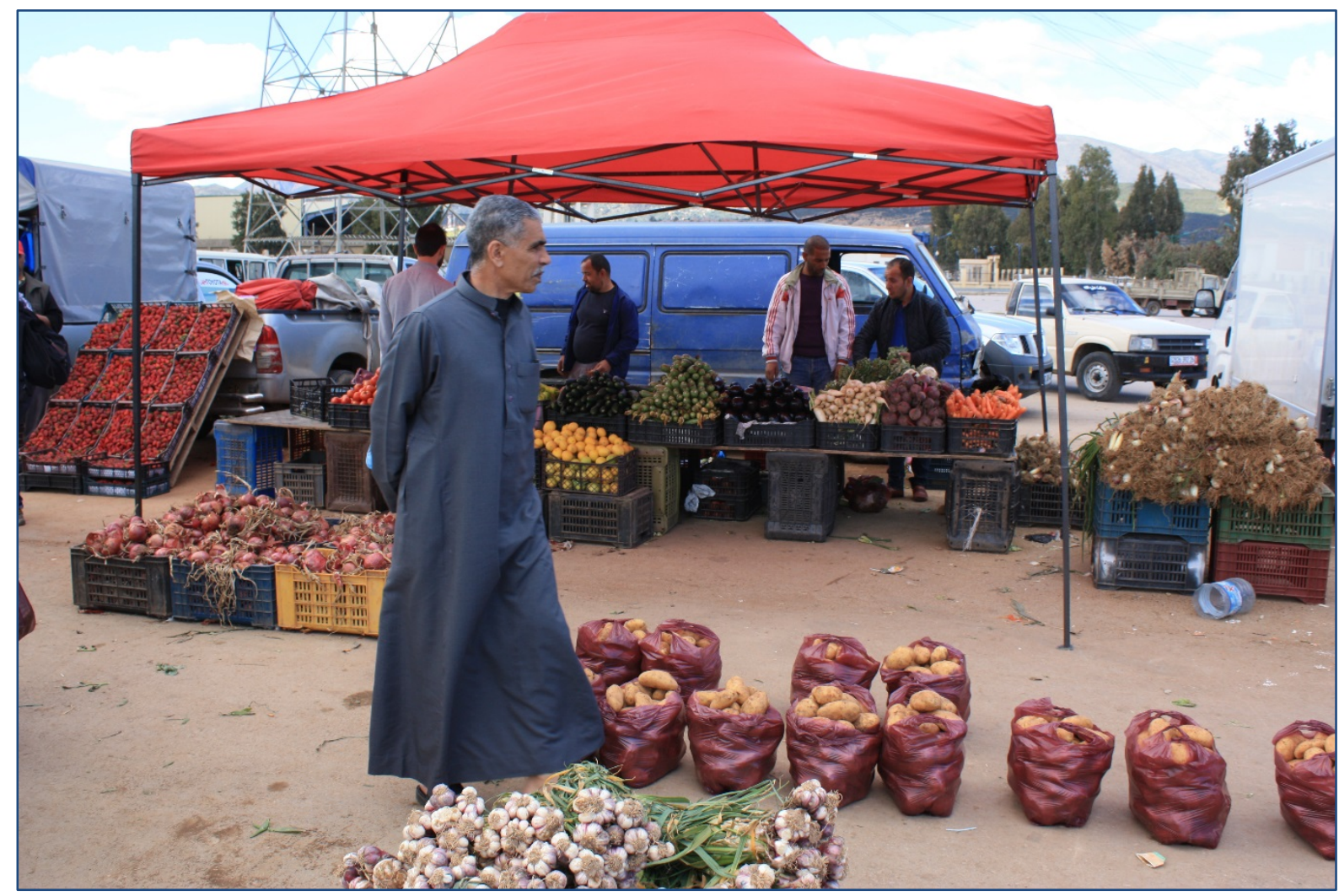




\section{Analysis of the potato chain}

In order to identify opportunities for the Dutch agricultural sector to do business in the Tunisian potato sector a SWOT analysis is carried out. Information is collected from interviews during the field visit in Tunisia from May 6-12, 2018 (see appendix).

\section{$5.1 \quad$ SWOT analysis}

The SWOT analysis is described in Table 9.

\begin{tabular}{|c|c|}
\hline hs & Weaknesses \\
\hline $\begin{array}{ll}- & \text { Yearly improvement return on investments } \\
\text { - } & \text { Trend to } 5 \text { growing seasons per year } \\
- & \text { Soon, year-round yield } \\
- & \text { Some farmers grow their own seed potatoes } \\
- & \text { Some farmers have high yields ( } 60 \text { ton/ha) } \\
- & \text { Big farmers receive more and more access to } \\
\text { finance and innovate (mechanisation, pest } \\
\text { control) } \\
\text { Program started in } 1977 \text { aiming at good } \\
\text { quality and climate controlled storage } \rightarrow \\
\text { So, Knowhow on innovation and technology } \\
\text { is present in Tunisia } \\
\text { Increase in specialisation and knowhow per } \\
\text { region (by introduction monocultures) }\end{array}$ & $\begin{array}{ll}- & \text { Field sizes too small }(40 \%<1 \text { ha) } \\
\text { - } & \text { Insufficient mechanisation; } \\
\text { - } & \text { No proper equipment available for small plots } \\
\text { - } & \text { Not enough pesticides; chemicals costly } \\
\text { - } & \text { Not enough labour } \\
\text { - } & \text { High losses by inadequate storage } \\
\text { - } & \text { Imbalance between supply and demand } \\
- & \text { Variability in price } \\
- & \text { Cost effectiveness too low (although } \\
- & \text { potential is present) } \\
- & \text { No monitoring of production flows } \\
- & \text { Young people leave the sector } \\
- & \text { Farmer ship is no professional occupation } \\
- & \text { Less knowhow by small farmers } \\
- & \text { Insufficient technical support and training } \\
\end{array}$ \\
\hline Opp & Threats \\
\hline 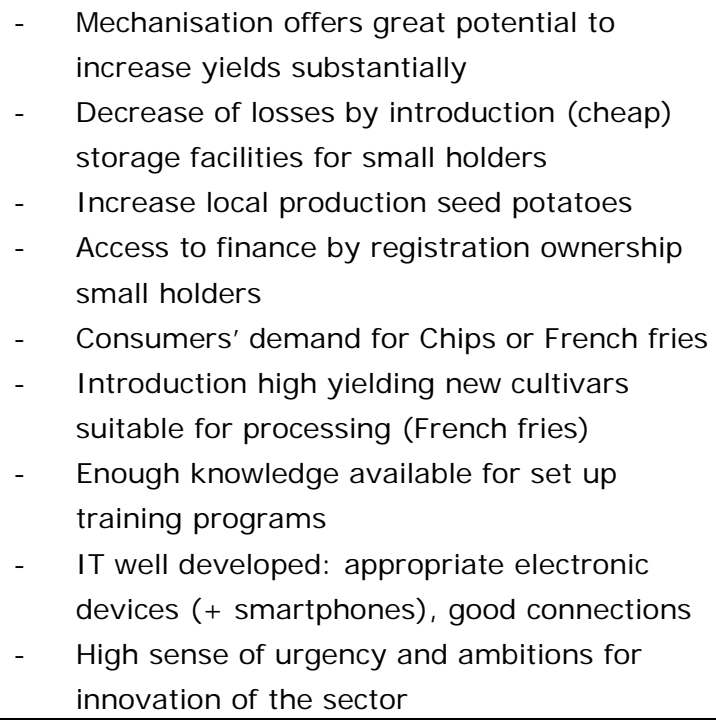 & $\begin{array}{ll}\text { - } & \text { Bad road network (especially in Northwest) } \\
\text { - } & \text { Lack of registration system } \\
\text { - } & \text { Speculators, mysterious middleman and } \\
\text { illegal practices } \\
\text { - } \quad \text { Imported potatoes and French fries are } \\
\text { cheap and highly competitive for local } \\
\text { market } \\
\text { - } \quad \text { Existing covenants with European countries } \\
\text { concerning import (French fries, etc.) } \\
\text { - } \quad \text { Farmers' reluctance to organize, distrust } \\
\text { - } \quad \text { Less interest in long-term planning } \\
\text { - } \quad \text { Lesubsidies }\end{array}$ \\
\hline
\end{tabular}

Table 9. Strengths, weaknesses, opportunities and threats of the potato sector in Tunisia

It is clear, that Tunisia has ample knowledge and skills in various agricultural areas and enough manpower to deploy jobs. However, on meta level the country is still lacking capacity to develop the agricultural sector towards its goals, such as:

- There is limited use of a value chain approach and a poorly developed agro logistics.

- $\quad$ No clear vision on chain management by suitable storing, packaging and marketing.

- Farmers (especially smallholders) are hardly organized and reluctant to get involved, which makes it difficult to create impact from government to farmers adequately involved. 
- Smallholders have limited access to knowledge as mutual communication between farmers is not well structured and it is not common practice to share knowledge between farmers. Meanwhile, the extension services are shrinking due to a decline of subsidy by the government.

- Smallholders do not have access to capital to invest in innovation and possibly have difficulties to find the right path to governmental subsidies.

- There is no strategy on future sustainability (like water saving, climate smart agriculture, closing of cycles by reuse of organic waste, integrated pest management, etc.).

- A registration or certification system of farmers is not well developed.

- Most small farmers do not systematically monitor their farm management activities or incidence of diseases, nor their yield or post-harvest yield losses. As long as quality control is absent, farmers do not feel any urgency to develop these skills.

As main problems in the potato sector can be considered: dependency on import of seed potatoes, variability in supply, fluctuation in the price system, low level of mechanisation and hardly any processing to mashed potatoes, chips, French fries or frozen potatoes. For small holders future perspectives are unfavourable. Often prices are too low to offer the farmer a return on investment, while imported potatoes can be even cheaper. As a result, many farmers combine different types of agricultural activities (like potato, tomato and a few cows).

Yet, the production volume of potatoes is still big and the Tunisian consumers prefer locally produced potatoes by far. Weak points that also complicate the potato chain are: insufficient transparency, distrust, no long-term perspective and parallel illegal and corrupt chains. However, the SWOT analysis show that there are different opportunities for innovation of the sector and improvement of the living of the potato small holder.

\subsection{Proposals to strengthen these weak points}

Since many (small) farmers have an enormous knowledge gap, knowledge transfer is an important step for innovation of the sector. Herewith, farmers should be trained in the improvement of farm management, registration, attention for sustainability using field technology for monitoring and control in agricultural fields (DSS) and climate smart agriculture, strengthening their entrepreneurship and learning marketing strategies to become independent from hawkers or speculators, quality control, etc. With the available knowledge in the Netherlands knowledge institutes could support Tunisia in order to select the best product market combinations in a market driven approach, and (re) design the supply chains by taking into consideration:

- hardware (e.g. infrastructure, logistics),

- 'orgware' (e.g. organization of stakeholders, alliances), and

- $\quad$ software (e.g. skills knowledge, transfer).

Important opportunities for private sector to improve the sector are the introduction of equipment for mechanisation and adequate storage facilities. In particular, the introduction of storage facilities (low, mid or high tech) for individual farmers or for collective use to hold potatoes for several months will dim the variability of the supply which will positively affect different weak points in the potato chain: the fluctuation in the price system, the oscillation between import and export of potatoes, reduction of losses, possibilities for local production of seed potatoes and, last but not least, the establishment of a processing chain as supply can become guaranteed. Storage of potatoes can support business of several stakeholders in the chain, as depicted in Table 10.

\begin{tabular}{|l|l|l|l|l|l|}
\hline & Farmer & Broker & Processor & Trader & Foodservice \\
\hline Price speculation & $\mathrm{x}$ & $\mathrm{x}$ & & $\mathrm{x}$ & \\
\hline Loss reduction & $\mathrm{x}$ & & & & \\
\hline Guarantee of supply & $\mathrm{x}$ & $\mathrm{x}$ & $\mathrm{x}$ & & $\mathrm{x}$ \\
\hline Expand market & & & & $\mathrm{x}$ & \\
\hline
\end{tabular}

Table 10. Effect of storage of potatoes on different aspects of the value chain and its stakeholders 
The sizes of the storage facilities depend on the number and type of farmers that are connected. For a 20 - 50 T storage, assuming an average yield of $4-6$ ton/ha per harvest, the required number of farmers is described in Table 11.

\begin{tabular}{|l|c|c|c|}
\hline \multicolumn{1}{|c|}{ Farmer type } & ha & Ton per harvest & Required number of farmers \\
\hline Small & 0.2 & 1 & $20-50$ \\
\hline Small/medium & 0.4 & 2 & $10-25$ \\
\hline Medium/large & 2 & 10 & $2-5$ \\
\hline Large & 10 & 50 & 1 \\
\hline
\end{tabular}

Table 11. Required number of farmers from different categories for sharing an 20 - 50 ton storage facility

To make the sector more transparent and professional, the introduction of a registration system and the setting up of network in which farmers can share knowledge, can get guidance and education and can be trained in farmer entrepreneurship to organise farmers towards an efficient market orientation.

To improve the pricing system, two possible approaches can be considered:

1. Introduction of subsidies for potato farmers, based on a proper registration system

2. Liberalisation of market prices (although it is a sensitive subject and may lead to commotion)

Availability of finances for small holders is a big problem when no subsidies are delivered. Moreover, farmers have no access to finance as long as they have no proper documentation about their business or ownership. As an incentive for famers, it is suggested to provide subsidies to farmers via farmer's based organisations. Keywords in this process are: farmer entrepreneurship, governance of farmer's organizations, economic services that these organizations can deliver to their members, stakeholder collaboration, policy environment, promoting farmer-inclusive value chain development.

Once farmers are organized in farmer's based organisations, a proper registration system can be set up, knowledge transfer can happen and farmers can be trained in new technologies. This affiliates to the ambitions in the national strategic plan Tunisia $(2018-2022)^{18}$ in which is stated in goal 33 of strategic implications for the World Food Program (WFP):

‘.. WFP will work with national authorities to establish frameworks for partnerships with smallholder farmers and community-based organizations and selection criteria for the identification of smallholders with the potential for supplying WFP. It will also support national authorities in measuring the benefits to smallholders in terms of increased market access ..'

Here, the introduction of farmer field schools (FFS), professional study groups, might be very useful. FFS are considered to be an adequate method for knowledge transfer and to introduce new production practices in Tunisia with the aim to increase productivity and sustainability (Davis et al., 2012). This would also enable the monitoring of the volume of cultivated and exported produce as well as its balance. Then, a development towards certification of the production base (HACCP, GlobalGAP, etc) can be established and the tariff relief granted from the EU may facilitate the access of potatoes from Tunisia in the European markets and their competitiveness ${ }^{19}$.

\footnotetext{
18 https://docs. wfp.org/api/documents/40c35cf3-4055-4588-9c89-e3e59ac6a483/download/ (accessed on 12-04-2018)

${ }^{19}$ http: //www. freshplaza.com/article/106730/Tunisian-potato-production, (accessed 09-04-2018)
} 


\section{Opportunities for the Dutch agricultural sector}

The Tunisian government has indicated its vivid interest in cooperation with the Dutch knowledge organisations in the agricultural field to support the socio-economic development in Tunisia. In order to support the Tunisian government in their agricultural goals for the coming years, cooperation with the Dutch government, knowledge organisations and private sector is helpful on: mechanisation, hardware and software for monitoring and control (DSS) towards a sustainable farm management, fertilisers, pesticides or systems for integrated pest management, introduction of storage devices, training on farm and chain management, entrepreneurship, marketing strategies, etc.

Especially for the potato sector, support from the Netherlands is requested on: help to work towards a produce of $100 \%$ potato seeds locally, help to further develop the value chain and mechanisation. This needs the introduction of other cultivars than Spunta and Nicola, namely cultivars suitable for processing. But also the import of mashed potatoes, chips, French fries or other frozen potato products might be helpful to give a boost to the Tunisian market for processed potatoes.

Dutch knowledge institutes have a long experience in the production of high quality seeds and (re)organization of potato supply chains, improving storage capacity and by doing so reducing food losses and increasing farmers' income. Also, the Netherlands is world-leading provider of potato storage solutions.

However, for the short run investment by the Dutch private sector is risky as long as the investment in added value does not guarantee direct returns on investment. Without a solid quality system and no pricing system in which the production of potatoes with high quality is paid back, such investment is not attractive. Introduction of professionalism and innovation of the sector will offer these opportunities on the long run. Yet, there are some exceptions that appear to be successful on the short run, like:

- Introduction of equipment and knowhow to produce potato seeds locally,

- $\quad$ Processing of potatoes within the chain for direct consumption,

- $\quad$ Introduction of farming equipment for small farms.

These exceptions will be elaborated further.

\subsection{Equipment and knowhow to produce seed locally}

Currently, only a small amount of the seed is locally produced. The majority $(\sim 85 \%)$ is imported (see Table 7). Table 12 shows the yearly costs to import potato seeds for the period $2012-2016$.

\begin{tabular}{|c|c|c|c|}
\hline Year & Net weight (ton) & Market Price (US\$/ton) & Trade Value (US\$) \\
\hline 2012 & 25820 & 755 & 19.489 .447 \\
\hline 2013 & 28135 & 793 & 22.311 .610 \\
\hline 2014 & 23466 & 783 & 18.381 .516 \\
\hline 2015 & 20078 & 650 & 13.050 .516 \\
\hline 2016 & 24377 & 650 & 15.846 .360 \\
\hline Average & 24375 & 731 & 17.815 .890 \\
\hline
\end{tabular}

Table 12. Net import seed potatoes (tonnes) in Tunisia and its costs (US\$) in the period $2012-2016$ 
Although, the market price is variable, average yearly import costs amounts to $\$ 731 /$ ton and justifies the aiming at an increase of local production. In order to reach this goal it will be important factor to introduce adequate storage devices (low, mid or high tech), either suitable for small holders as for bigger quantities, which may be dealt by different farmers.

Apart from storage equipment, know how on the production of high yielding and high quality seeds is also needed and explicitly requested by the interviewees. Dutch companies have opportunities to bring in 1) new varieties suitable for the Tunisian market and diet requirements of the Tunisian consumers and 2) knowhow on farm management and integrated pest control (IPM) to start a development towards certification (HCCP, GlobalGAP, etc.).

\subsection{Processing of potatoes within the chain}

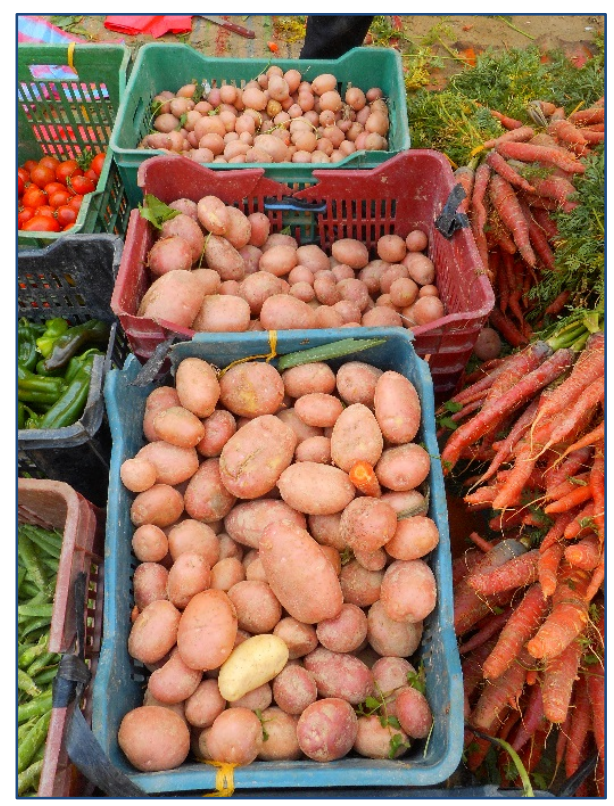

In developing markets, the potato consumption in fresh form is still much higher than in processed form. However, with an increase in urbanisation, flow of young fast food consumers to the cities and extension of the middle class, an increase of processed potato products can be noted all over the world. This is because the middle class can afford to buy (potato) snacks and eat at restaurants. Moreover, the emerge of a fast food sector that usually serves French fries, is strongly related to the presence of a middle class in emerging economies. In Tunisia, the middle class is also growing ${ }^{20}$ implying that the consumption of processed potatoes will rise. This trend is supported by the launching of the first MacDonalds ${ }^{21}$ and the first Kentucky Fried Chicken ${ }^{22}$ by the beginning of this year in Tunis.

The value chain of processing of potatoes (mashed potatoes, chips, French fries) can be developed towards different stages of complexity, different amounts of investments and different needs for training and capacity building. The processing of potatoes to fresh French fries to be consumed directly (in restaurants or hotels) can be a start with short-term potential and perspective. Cooperation with the existing factory Mad Chips ${ }^{23}$ is recommended. It will enable to use the network of the factory and it will become an opportunity to boost the production of the factory and its continuity.

For realisation, the introduction of equipment for storage, peeling and cutting is needed. Processing also needs special varieties with better product characteristics, longer dormancy and preferably consistency in quality. The cultivar Spunta is not very suitable to become processed into French fries. Varieties more appropriate for processing are for example variety 'Jelly' (Europlant) and 'Markies' (Agrico). Constraints are that the cultivars can be registered, continuous supply is secured from different suppliers and different regions and the distribution system is efficient.

The development of a value chain for frozen products might be too ambitious for the short term. This kind of processing needs a big supply by a great number of contracted farmers, expensive cold storage, a well-developed distribution network and guaranteed market. The big international players in this segment (McCain, FarmFrites, Simplot, LambWeston and Aviko) are not expected to come to

\footnotetext{
20 https://www.brookings.edu/blog/future-development/2016/03/18/middle-class-dynamics-and-the-arab-spring/ (accessed on 29-05-2018)

21 https://en.wikipedia.org/wiki/List_of_countries_with_McDonald\%27s_restaurants

22 http://www.hbg-holding.com/en/news/ouverture-premier-restaurant-kfc-tunisie

${ }^{23}$ Usine ZI Siliana 2, Siliana Bureaux ZI Mghira 3,Ben Arous; TEL :00216 $71409626 / 71409628$
} 
Tunisia any time soon. In the meantime the fast food sector imports pre-fried frozen French fries from South Africa (McCain) and Egypt (Farm Frites) at relative low prices.

\subsection{Farming equipment suitable for small fields}

The level of mechanisation in the potato sector is low. The majority of the small holders do their field preparations, planting, farm management and harvesting manually. Introduction of equipment for soil cultivation, potato planting, harvest equipment, storage equipment will substantially increase yield and decrease losses. However, as most fields are very small ( < 1ha), special equipment is needed for farm management at small areas. Moreover, the equipment has to be robust enough to be used at tough soil types. This pleas for the introduction of equipment as in the Netherlands used for small plots, experiments, orchards, etc., like the 2-row potato windrower.

\subsection{Actors for business opportunities}

The SWOT analysis shows that Tunisia has different opportunities for short-term innovation in the potato sector. For both Tunisia as the Netherlands work can be done for realisation of the goals described in the Memorandum of Understanding, signed by the Dutch Ministry of Foreign Affairs and the Tunisian Ministry of Agriculture and Water Resources.

\subsubsection{Dutch actors}

Table 13 shows in summary the type of Dutch companies, that may be interested in doing business with Tunisia, what can be supplied and what kind of activities are identified:

\begin{tabular}{|c|c|c|c|c|c|}
\hline & Mechanisation & $\begin{array}{l}\text { Introduction } \\
\text { storage } \\
\text { equipment }\end{array}$ & $\begin{array}{l}\text { Local } \\
\text { production } \\
\text { seed potatoes }\end{array}$ & $\begin{array}{l}\text { Processing } \\
\text { potatoes }\end{array}$ & $\begin{array}{l}\text { Registration and } \\
\text { professionalization }\end{array}$ \\
\hline Breeders (seed) & & & Know how & $\begin{array}{l}\text { Introduction new } \\
\text { suitable cultivars }\end{array}$ & \\
\hline $\begin{array}{l}\text { Suppliers } \\
\text { equipment }\end{array}$ & $\begin{array}{l}\text { Soil cultivation, } \\
\text { Planting, } \\
\text { Harvesting, } \\
\text { Knowledge }\end{array}$ & & & $\begin{array}{l}\text { Peeling equipment } \\
\text { Cutting equipment }\end{array}$ & \\
\hline $\begin{array}{l}\text { I PM, biological } \\
\text { systems }\end{array}$ & $\begin{array}{l}\text { Supply predators } \\
\text { for Pest control, } \\
\text { Knowledge } \\
\end{array}$ & & & & \\
\hline $\begin{array}{l}\text { Suppliers of } \\
\text { hardware \& } \\
\text { software }\end{array}$ & $\begin{array}{l}\text { Sensors, } \\
\text { Software } \\
\text { (fertilisation, } \\
\text { wateruse) } \\
\end{array}$ & & $\begin{array}{l}\text { Sensors, } \\
\text { Software } \\
\text { (fertilisation, } \\
\text { wateruse) } \\
\end{array}$ & & Registration system \\
\hline $\begin{array}{l}\text { Suppliers of } \\
\text { (cold) Storage }\end{array}$ & & $\begin{array}{l}\text { Equipment, } \\
\text { Training }\end{array}$ & & $\begin{array}{l}\text { Storage facilities } \\
\text { (low, mid or high } \\
\text { tech) }\end{array}$ & \\
\hline $\begin{array}{l}\text { Service } \\
\text { providers }\end{array}$ & & & & & $\begin{array}{l}\text { Labs, } \\
\text { Inspection, } \\
\text { Capacity building }\end{array}$ \\
\hline $\begin{array}{l}\text { Financial } \\
\text { institutions }\end{array}$ & $\begin{array}{l}\text { Agrifinance } \\
\text { solutions (micro } \\
\text { credits) }\end{array}$ & $\begin{array}{l}\text { Agrifinance } \\
\text { solutions } \\
\text { (micro credits) }\end{array}$ & $\begin{array}{l}\text { Agrifinance } \\
\text { solutions (micro } \\
\text { credits) }\end{array}$ & & \\
\hline
\end{tabular}

Table 13. Business opportunities in Tunisia for different companies 


\subsubsection{Tunisian actors}

In Tunisia most important actors for cooperation are summarized in Table 14 (more details on characteristics of the organisations and contact info are mentioned in Annexes I and II). All distribution of potatoes connected with the national seed program, from import of seed tubers and their distribution to contract farmers to collection, storage, and sale to ware producers of locally multiplied seed is handled by GIL. Evaluation of varieties for importation as seed tubers is handled by the research organizations of the Ministry of Agriculture.

\begin{tabular}{|c|c|c|c|c|}
\hline & Organisation & Department & Name & Function \\
\hline \multirow[t]{3}{*}{1} & \multirow{3}{*}{$\begin{array}{l}\text { Ministry of Agriculture } \\
\text { and Water Resources }\end{array}$} & \multirow{2}{*}{$\begin{array}{l}\text { Agricultural extension and } \\
\text { Training Centre }\end{array}$} & Zayani Khemales & General Director \\
\hline & & & Aniss Ben Rayana & $\begin{array}{l}\text { Coordinateur du bureau de la } \\
\text { Coopération Internationale }\end{array}$ \\
\hline & & $\begin{array}{l}\text { Direction Général de la } \\
\text { protection et du controle }\end{array}$ & & \\
\hline \multirow[t]{2}{*}{2} & \multirow{2}{*}{$\begin{array}{l}\text { National Institute of } \\
\text { Agronomy, Tunis } \\
\text { (INAT) }\end{array}$} & & Prof. Djemali Mnaouer & Professor \\
\hline & & & Chniter Mohammed & Assistant \\
\hline 3 & $\begin{array}{l}\text { Végétales } \\
\text { Interprofessionnel } \\
\text { Group (GIL) }\end{array}$ & & Ismail Ghezal & General Director \\
\hline \multirow[t]{2}{*}{4} & \multirow{2}{*}{$\begin{array}{l}\text { Centre Technique de } \\
\text { la Pomme de terre et } \\
\text { de l'Artichaut (CTPTA) }\end{array}$} & & Khalifa Rachid & $\begin{array}{l}\text { Chef service stockage et } \\
\text { transformation }\end{array}$ \\
\hline & & & $\begin{array}{l}\text { Essid Mohamed } \\
\text { Farouk }\end{array}$ & $\begin{array}{l}\text { Chef service physiologie et } \\
\text { sélection variétale }\end{array}$ \\
\hline 5 & $\begin{array}{l}\text { Institution de la } \\
\text { Recherche et de } \\
\text { I'Enseignement } \\
\text { Supérieur Agricoles } \\
\text { (IRESA) }\end{array}$ & & $\begin{array}{l}\text { Prof. Mahmoud Elies } \\
\text { Hamza }\end{array}$ & President \\
\hline 6 & $\begin{array}{l}\text { Développement } \\
\text { Agricole de Manoubaa }\end{array}$ & & Hedi Hamrouni & $\begin{array}{l}\text { Le Commissaire Régional au } \\
\text { Développement Agricole de } \\
\text { Manoubaa }\end{array}$ \\
\hline \multirow[t]{2}{*}{7} & \multirow[t]{2}{*}{ Advans } & & Aymen Taboubi & Agricultural operations \\
\hline & & & Elliott Saint Gilles & Project Agriculture \\
\hline 8 & $\begin{array}{l}\text { Syndicat des } \\
\text { Agriculteurs de Tunisie }\end{array}$ & & $\begin{array}{l}\text { Ezzeddine ben } \\
\text { Mustapha }\end{array}$ & $\begin{array}{l}\text { Membre du bureau exécutif; } \\
\text { farmer in Utique }\end{array}$ \\
\hline \multirow[t]{2}{*}{9} & \multirow[t]{2}{*}{ Carrefour } & & Lamine Ben Ali & Acquisition \\
\hline & & & Mourad Hichri & Responsable fresh products \\
\hline 10 & General potato center & & http://www.ctpta.tn/ & \\
\hline \multirow[t]{2}{*}{11} & \multirow[t]{2}{*}{ FAO } & & Ahmed Bougacha & $\begin{array}{l}\text { Assistant au Représentant de } \\
\text { la FAO en Tunisie Programme }\end{array}$ \\
\hline & & & Michael George Hage & Coordinator forNorth Africa \\
\hline 12 & Mad Chips & & & \\
\hline 13 & $\begin{array}{l}\text { Observatoire Nationale } \\
\text { d'Agriculture } \\
\text { (ONAGRI) }\end{array}$ & & & General Director \\
\hline
\end{tabular}

Table 14. Important Tunisian actors in the agricultural sector, having potato in their dossier. 


\section{$7 \quad$ Doing business in Tunisia}

The attractiveness of Tunisia to Dutch companies is not depending on business opportunities only. The complexity of starting up a business, to get electricity or permits is just as relevant. Also taxes, import regulations and cultural aspects are decisive elements before entering a new country for business. Annually the Word Bank Group launches country reports and provides objective measures of business regulations and their enforcement across 190 economies and selected cities at the subnational and regional level. For Tunisia the overall result is shown in Figure 8.

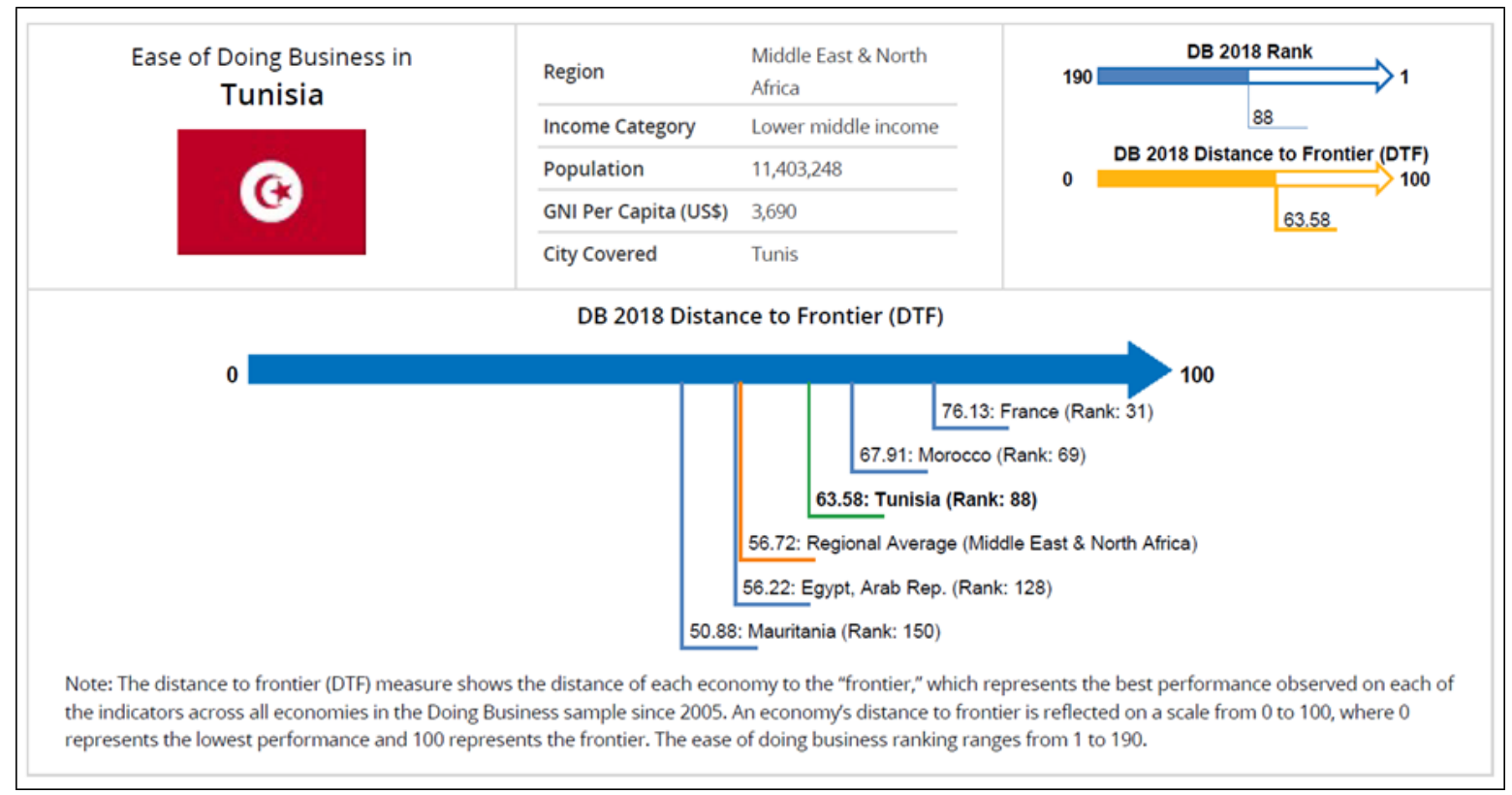

Figure 8: ease of Doing Business in Tunisia in 2018 according to the World Bank

Tunisia scores relatively well on energy supply (electricity, gas) and not so well on paying taxes (Group, 2018).

\subsection{Business environment}

Although Tunisia is not well known to investors the country is ahead of many African countries with respect to all kinds of infrastructure:

- $\quad$ The proximity of the EU and other surrounding markets (the Maghreb and Middle East)

- A developed transportation system

- Tunisia benefits from eight commercial ports equipped to accommodate a variety of different methods of transportation

- The ports of Marseille, Gêne and Barcelona are all relatively close to Tunis

- Airport infrastructure is composed of seven international airports apportioned across the whole territory and frequented by the main airlines of Europe, the Middle East and Africa

- The road network, of more than 32,000 kilometres, allows easy access to all regions of the country

- An effective telecommunication network, in which enormous investments have been made to develop a modern telecommunication system covering all regions of the country

In addition there are various financial incentives for investment in agriculture:

- Total exemption from tax on reinvested profits and income

- Total exemption from tax for the first ten years of operation 
- A premium about $7 \%$ of the value of the investment

- $8 \%$ an additional premium of the value of the investment may be granted for agricultural investment in areas with harsh climate: Gabes, Gafsa, Medenine Kebili, Tataouine and Tozeur

- Suspension of VAT on imported capital goods which have not been manufactured locally

- The possibility of state participation in expenditure for infrastructure development areas for aquaculture and crops using geothermal energy.

Especially the last one is interesting for greenhouse investment near the geothermal zones.

For investments by companies for projects of environmental protection and waste treatment, which is mentioned as one of the opportunities, the Code provides for the following advantages:

- Abatement of $50 \%$ of revenues or profits reinvested

- Tax rate reduced to $10 \%$ of revenues and profits

- Bonus $20 \%$ of the value of investments

- Suspension of VAT for most of the goods.

There are more details (e.g. about labour) to be found in UHY, Doing business in Tunisia, 2014: p 26.

\subsection{Starting a business}

Starting a business in agriculture can be undertaken as a 'one-stop-shop' supported by the Agency of Promotion of the Agricultural Investments (APIA). The set-up process is as follows:

a) Deposit capital in a bank opened in the name of the company to be incorporated

b) Register the articles of association with tax administration at the API and obtain a certificate attesting that a declaration has been filed

c) File a declaration of existence with the Tax Control Desk at the API ${ }^{24}$ and obtain a 'carte d'identification fiscale'. The documents required to make the declaration are:

- Printed signature form

- Registered copy of the articles of association

- Copy of the minutes of the nomination of the managers (if not designated by the articles)

- Copy of the managers' national identity cards (copy of passports for foreigners) opy of the rent agreement or the certificate of ownership of the premises where the head office is located

- Any administrative authorisation that would be required to start the business

d) Deposit documents at the 'Greffe of Tribunal'. The following documents are required:

- Printed forms ( provided by the Greffe of Tribunal office) for the depositors to complete and sign

- Declaration of honour signed by the managers

- Registered statutes

- Minutes that nominate the managers (if not designated by the articles of association)

- Arabic translation of the main clauses of the articles

- Declaration of the beginning of the business with the tax administration and tax identification card

- Document providing the headquarters address

- National identity card (or passport for foreigners) of the company manager(s)

- Fiscal stamp

- A proxy, if the formalities are undertaken by a party other than the manager

e) Advertise in the Official Gazette (JORT) with the Government Printing Office and in two dailies, one preferably in Arabic

f) Register with the registrar (Registre of Commerce at the Greffe of Tribunal)

g) Register for social security

${ }^{24}$ Agency of Promotion of the Industry 
h) Get inspected by the National Social Security Fund (CNSS)

i) File a declaration with the labour inspectorate.

\subsection{Experience from Dutch investors}

Real life experience is withdrawn from interviews with three companies operating in Tunisia:

1. Desert Joy, tomato grower, El Hamma, Gabes, Tunisia

2. A. en G. van den Bosch B.V, beef tomato grower, El Hamma, Gabes, Tunisia

3. Grow Tunisia SARL, crafted plants for vegetables, especially cucumbers and tomatoes, Megrine, Tunis, Tunisia

\section{General:}

- $\quad$ There is a lot of bureaucracy

- The Dutch have a positive imago with respect to potatoes, dairy and tomatoes

- The political situation in Tunisia is okay for now, but the situation is hard to predict. Therefore it is wise to take small steps forward

- Talking French or Arabic is a must since many people don't speak English, especially in labour

- A local partner is necessary to deal with local banks, government and taxes

- Availability of educated staff

Logistics:

- Tunisia is relatively close to Europe. The trip from the greenhouse area in Morocco takes longer than from Tunisia

- $\quad$ The shipping from Tunisia to Marseille should remain reliable. The line is getting more busy implying risk for delays.

Culture:

- Religion plays an important role, also at work. Especially Ramadan is a crucial period with respect to planning

Technology:

- Fiberglass is put in the ground until the border of the Sahar, hence the internet access is fine

Money:

- As shown in figure 9. the inflation rate is increasing since January 2016 from $3.2 \%$ until $7.7 \%$ in April $2018^{25}$. Hence investments from Dutch companies are not sourced from Tunisian banks, but from the Netherlands.

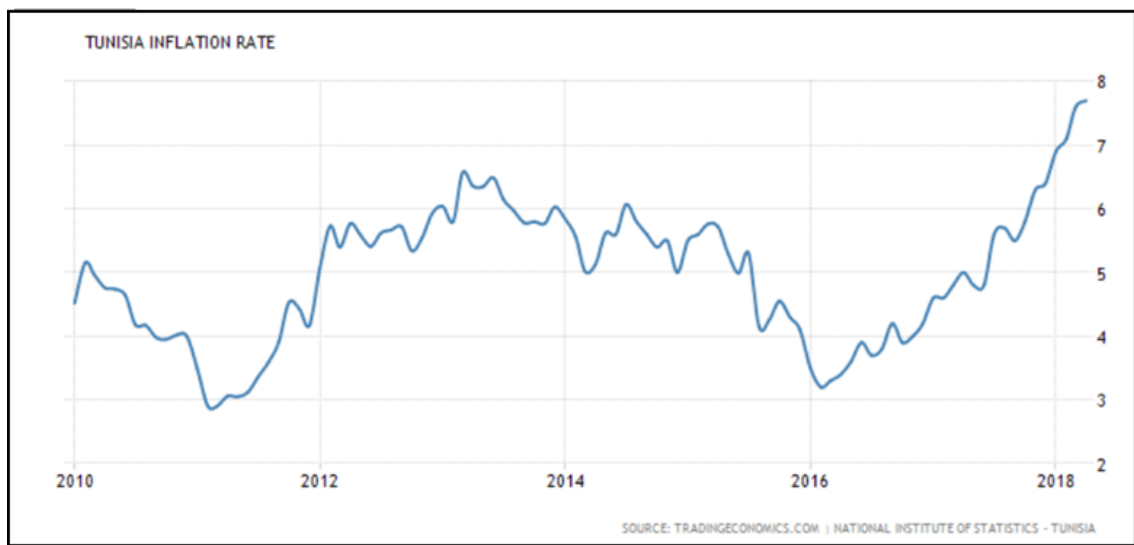

Figure 9: inflation rate Tunisia 2010-2018

Product related:

- Tunisia enables a Dutch grower to supply the market

$\overline{25}$ https://tradingeconomics.com/tunisia/inflation-cpi, viewed 22-5-2018 
- Knowledge and experience on production and climate control is not yet developed in Tunisia; in future probably electronically controlled 


\section{Conclusions}

From this study, it can be concluded that the value chain is not fully developed. The main focus of the potato chain is on primary production. Most of the produced potatoes are directly consumed, while processing of potatoes hardly occurs.

The current situation for small holders in the potato sector is unfavourable. As main problems in the potato sector can be considered:

- dependency on import of seed potatoes

- variability in supply

- both import and export of ware potatoes by imbalance of supply and demand

- too low prices for the farmer to offer the farmer a return on investment, while imported potatoes can be even cheaper

- fluctuation in the price system

- low level of mechanisation and

- high yield losses.

Weak points that complicate the potato chain are:

- insufficient transparency,

- distrust,

- no long-term perspective,

- parallel illegal and corrupt chains,

- no organisation and no registration.

However, the SWOT analysis show that there are different opportunities for innovation of the sector and improvement of the living of the potato small holder. Important opportunities for improvement of the sector are the introduction of equipment for mechanisation and adequate storage facilities. The introduction of storage facilities (low, mid or high tech) to hold potatoes for several months will dim the variability of the supply which will positively affect:

- the fluctuation in the price system

- $\quad$ the oscillation between import and export of potatoes

- reduction of losses

- possibilities for local production of seed potatoes and

- $\quad$ the establishment of a processing chain as supply can become guaranteed.

To make the sector more transparent and professional, the introduction of a registration system is proposed, as well as the setting up of a network in which farmers can share knowledge, can get guidance and education and can be trained in farmer entrepreneurship to organise farmers towards an efficient market orientation.

To affect the pricing system, following measures to be taken by the government are mentioned: Introduction of subsidies for potato farmers, based on a proper registration system and Liberalisation of market prices.

As perspective business case for Dutch companies can be considered:

1) Supply of storage equipment and knowhow to produce all seed potatoes locally in combination with the introduction of a sustainable farming system (new varieties, DSS, IPM) and quality control 2) Development of the processing of potatoes within the chain (Chips, French fries) in combination with the introduction of adequate storage equipment and know how on chain management and packaging. 


\section{References}

African Development Bank, Tunisia - country strategy paper 2017-2021. 2017

Ben Abdelkrim A, Hattab T, Fakhfakh H, Belkadhi MS, Gorsane F (2017) A landscape genetic analysis of important agricultural pest species in Tunisia: The whitefly Bemisia tabaci. PLoS ONE 12(10): e0185724. https://doi.org/10.1371/journal. pone.0185724

Besbes, M., Hamdane, A., Chahed, J. and Hamza, M. 2008. Tunisia Case Study Report (French), executive summary. In: World Water Assessment Programme, 2009. The United Nations World Water Development Report 3, Case Study Volume: Facing The Challenges.

Besbes, M.; Chahed, J.; Hamdane, A. \& De Marsily, G. (2010). Changing Water Resources and Food Supply in Arid Zones: Tunisia. In: G. Schneider-Madanes \& M.F Courel (eds.), Water and Sustainability in Arid Regions 2010, 1, pp 103-121. Springer.

Blom-Zandstra, G., H. Axmann, H. Heesmans, 2017. Needs Assessment of the Agriculture in NorthWest Tunisia; Evaluation of the key priorities for agricultural resilience. Wageningen Research, Report WPR-720, 30 pp.

Chahed J., M. Besbes, A. Hamdane, 2010. Water scarcity and food security: A global assessment of water potentiality in Tunisia. In: Luis Martinez-Cortina, Alberto Garrido, Elena Lopez-Gunn (Editors), Re-thinking Water and Food Security, Fourth Botin Foundation Water Workshop, Taylor $\&$ Francis Ltd, September 2010, ISBN 0415587905

Davis, K., Nkonya, E., Kato, E., Mekonnen, D., Odendo, M., Miiro, R. and Nkuba, J. (2012). Impact of Farmer Field Schools on Agricultural Productivity and Poverty in East Africa. World Development, 40(2), pp.402-413.

Gaaloul, N., 2008. The Role of Groundwater During Drought in Tunisia. In: Zereini, F. and H. Hötzl (eds), Climatic Changes and Water Resources in the Middle East and in North Africa, pp 239-266. Springer.

Ghodbane, T. 1980. Report on potato Production in Tunisia. International Potato Course: Production, Storage, and Seed Technology. Report of Participants. International Agricultural Center, Wageningen, The Netherlands.

Group, W.B., Doing business 2018 - Reforming to create jobs - Economy profile Tunisia. 2018: p. 66.

Hamza, M., 2006. Etat, défis majeurs et axes stratégiques du secteur de l'eau en Tunisie. Rapport national. Ministère de l'agriculture et des ressources hydrauliques direction générale des ressources en eau. Conférence des directeurs de l'eau des pays Euro- Méditerranéens et de l'Europe du sudest Athenes, 6-7 novembre 2006.

Horton, D., R. Cortbaoui, H. Hattab, \& A. Monares 1986. Impact of Agricultural Research and Development: A Seed Potato Project in Tunisia. International Potato Center, Lima.

Jacobs, C. and C.E. van 't Klooster, 2012. Water and agriculture in the Magreb, Wageningen : Alterra, Wageningen-UR (Alterra-rapport) 354, pp 89

Lebdi, F., 2009. Contraintes de l'agriculture irriguée aux opportunités du marché, Cas de la Tunisie. Les Notes d'analyse du CIHEAM, n 51 - Septembre 2009.

Observatoire National de l'Agriculture (ONAGRI), Ministère de l'Agriculture, des Ressources Hydrauliques et de la Pêche, http://www.onagri.tn/

PAPS.-EAU, 2010. Programme d'Appui aux Politiques Publiques de gestion des ressources en eau pour le développement rural et agricole en Tunisie. Délégation de l'Union europénne en Tunisie. 27 May 2010. Powerpoint.

Soltane, B.B., New Tunisia - New economic vision. 2017.

Tabet, M., et al., 2013. Business opportunities in the Mediterranean - focus on agri-food in Tunisia.

Thabet B., Boughzala M., Ben Ammar B. 1994. Agriculture and food policy in Tunisia. In : Allaya M. (comp.), Thabet B. (comp.), Allaya M. (collab.), Thabet B. (collab.). Food and agricultural policies in the Middle East and North Africa: Egypt, Lebanon, Morocco, Sudan, Tunisia, Turkey. Montpellier: CIHEAM, 1994. p. 181-220 (Cahiers Options Méditerranéennes; n. 7)

You, H., H. Jin, A. Khaldi, M. Kwak, T. Lee, I. Khaine, J. Jang, H. Lee, I. Kim, T. Ahn, J. Song, Y. Song, A. Khorchani, B. Stiti and S. Woo, 2016. Plant diversity in different bioclimatic zones in Tunisia, Journal of Asia-Pacific Biodiversity 9, 56-62 


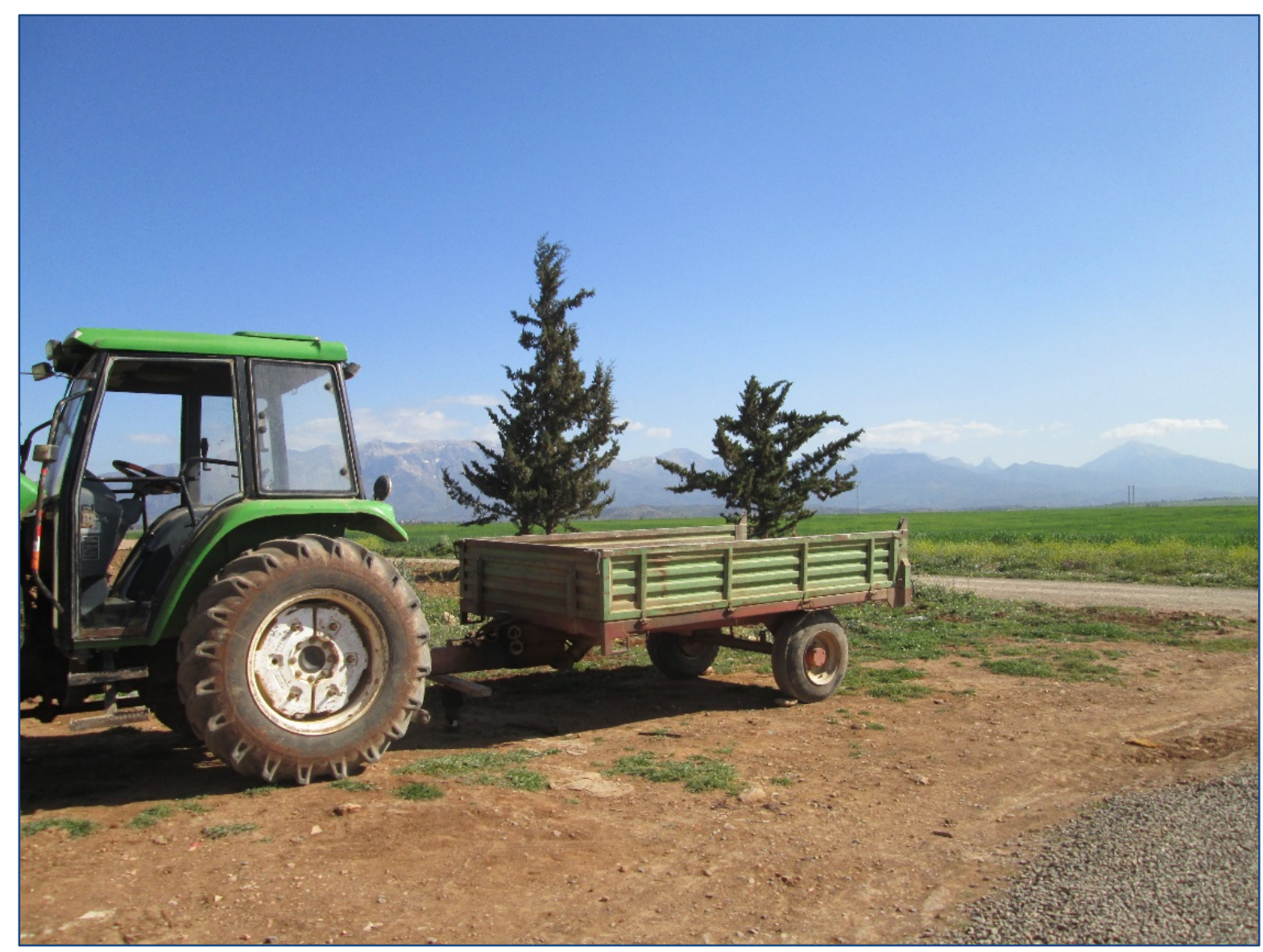

UHY, Doing business in tunisia. 2014: p. 26

ZEF, FARA, and INRAT, Innovation for Sustainable Agricultural Growth in Tunisia, 2017. 


\section{Annex 1 Organisations and contacts}

\section{Governmental organisations}

\begin{tabular}{|c|c|c|c|}
\hline \multicolumn{4}{|c|}{ The Ministry of Agriculture and Hydraulic Resources (MARH) } \\
\hline \multicolumn{4}{|c|}{$\begin{array}{l}\text { The MARH mission is to carry out, in coordination with the departments concerned, the state policy in } \\
\text { agriculture and fisheries, to ensure the promotion of this sector and to promote the creation of a } \\
\text { favourable climate for its development. }\end{array}$} \\
\hline Name & Function & Phone & Email \\
\hline \multicolumn{4}{|c|}{ Livestock and Pasture Office: } \\
\hline Mohamed Nasri & General Director & & dga@oep.nat.tn \\
\hline Naziha Dridi Hajlaoui & Adjoint General Director) & & dga@oep.nat.tn \\
\hline ana Zitouni & $\begin{array}{l}\text { Chief Engineer Specialist in } \\
\text { Animal Production }\end{array}$ & & sana.zitouni1@gmail.com \\
\hline \multicolumn{4}{|c|}{ Agricultural extension and Training Center: } \\
\hline Zayani Khemales & General Director & +21671795463 & zayani.khemais@inat.agrinet.tn \\
\hline niss Ben Rayana & $\begin{array}{l}\text { Coordinateur du bureau de } \\
\text { la Coopération } \\
\text { Internationale }\end{array}$ & +21671793185 & Benrayana.aniss@iresa.agrinet.tr \\
\hline \multicolumn{4}{|c|}{ Regional Offices of Agricultural Development (CRDA) } \\
\hline \multicolumn{4}{|c|}{$\begin{array}{l}\text { The regional organisation of the Ministry of Agriculture is governed by Decree } n^{\circ} 89-457 \text { of } 24 \text { March } \\
1989, \text { which delegates the Ministry's powers for agricultural production to the Governors. As such, a } \\
\text { CRDA was set up in each Governorate as an administrative public establishment with legal status and } \\
\text { financial autonomy. It is managed by a Commissioner appointed by decree based on a proposal made } \\
\text { by the Ministry of Agriculture. The CRDA is responsible for implementing State agricultural policy in } \\
\text { the Governorate. It undertakes regional development activities and carries out all specific tasks that } \\
\text { are entrusted to it by the current legislation and regulations. }\end{array}$} \\
\hline
\end{tabular}

\section{Group of Food Canning processors ( GICA)}

GICA is a public economic utility, placed under the supervision of the Ministry of Industry, it brings together professionals from the fruit, vegetable and fish processing industries

\section{The Agriculture I nvestment Promotion Agency (API A)}

APIA is a non-administrative public establishment reporting to the Ministry of Agriculture. Its mission consists of encouraging, promoting and assisting investments in agriculture, fisheries and associated services as well as in first-level processing connected to farming and fisheries projects. APIA is crucial for foreign investors since they have an Investor Liaison Office (one-stop shop) in Tunis.

\section{The Agricultural Extension and Training Agency (AVFA)}

AFVA is an administrative public establishment placed under the authority of the Ministry of Agriculture. It monitors the implementation of programmes pertaining to social and economic development plans, essentially in terms of training and extension.

\section{Tunisian Union of Industry, Trade and Crafts (UTI CA)}

The Tunisian Union of Industry, Commerce and Handicrafts is the national employers' centre; it brings together the professional structures of the different non-agricultural economic sectors (Industry, Trade, Services, Crafts and Small Professions). UTICA represents nearly 150,000 private companies from all sectors of activity (with the exception of Tourism and Banking and Finance). Most of these member companies are small and medium-sized enterprises. UTICA has more than 25,000 trade union leaders. Our mission revolves around actions to promote and energize the private sector, while being the spokesperson for companies with the public authorities. It plays a role in the pricing system for tomatoes.

\section{The Tunisian Union of Agriculture and Fisheries (UTAP)}

The Tunisian Union for Agriculture and Fisheries (UTAP) is a national organization of farmers and fishermen in multidisciplinary regional unions and specialized national federations. UTAP acts like a union of farmers and fishermen whose interests it defends; it also plays a role in the promotion of the profession and works closely with the administration of which she is the main contact. It plays a role in the pricing system, dissemination and promotional activities of breeding.

\section{Interprofessional Association for Vegetables ( GI L)}

GIL is placed under the supervision of the Ministry of Agriculture and Water Resources and administered by a board of directors composed of twelve members, one-third of whom represents the administration. It's mission is: 
- Liaise between the different phases through which products pass through the value chains, help producers to integrate and encourage producers, processors and traders of agricultural products to work through production contracts,

- Facilitate consultation between professionals and the administration in order to set the objectives of the various sectors,

- $\quad$ Contribute to the balance of the market by using the various appropriate mechanisms and in collaboration and coordination with the professional and administrative organizations concerned,

- To participate in the promotion of the export in collaboration and coordination with the professional and administrative organizations concerned,

- Collect, analyze and archive information, set up data banks relating to the sectors that are the subject of their intervention, and carry out studies on the reality and prospects of these sectors at national and international level

\begin{tabular}{|l|l|l|l|}
\hline Name & Function & Phone & Email \\
\hline I smail Ghezal & Director-General & +21671285522 \\
& & +21699141542 (mobile) & ghezal.iagronome@gmail.com \\
\hline
\end{tabular}

\section{Centre Technique de la Pomme de terre et de l'Artichaut (CTPTA)}

- Contribute to the identification of potato production areas intended for propagation or consumption, in cooperation with the parties involved

- Contribute to the control farm management conditions during the production of potato seeds

- Technical framing of producers using potato seed propagation activities

- Work on the introduction of mechanization that fits the specific characteristics of agricultural companies

- Identification of new high-yield varieties that have been adapted

- Control of economically viable technical systems with regard to irrigation, fertilization and remediation

- Feasibility studies of different potato production techniques

- Work on the development of potato processing industries

- Promoting the identification of exportable species in the context of production programs aimed at foreign markets

- $\quad$ Provide direct technical services to potato growers on request

- Study and development of traditional storage methods

\begin{tabular}{|l|l|l|l|}
\hline Name & Function & Phone & \\
\hline Khalifa Rachid & $\begin{array}{l}\text { Chef service stockage et } \\
\text { transformation }\end{array}$ & +2197551553 & kharachid@yahoo.fr \\
\hline Essid Mohamed Farouk & $\begin{array}{l}\text { Chef service physiologie } \\
\text { et sélection variétale }\end{array}$ & +2158898789 & essidinat@yahoo.fr \\
\hline
\end{tabular}

\section{University}

\section{Institution of Agricultural Research and Higher Education (I RESA) / Carthage} University / National Institute of Agronomics Tunis

The Institution of Agricultural Research and Higher Education is a public administrative institution which is financially autonomous, and has the following mission:

- Watching over the promotion of agricultural research within the framework of the Government's general policy while securing the liaison between agricultural research and higher education institutions on the one hand and agriculture producers on the other,

- Drawing up agricultural research programs and necessary budgets, following up the implementation of these programs and coordinating the work of research and higher education institutions in the field of agriculture.

- Making sure that agricultural research and higher education institutions are working for the farming production and their development.

\begin{tabular}{|l|l|l|l|}
\hline Name & Function & Phone & Email \\
\hline Prof. Mahmoud Elies Hamza & Director & +21671840270 & elies.hamza@iresa.agrinet.tn \\
\hline Aniss Ben Rayana & & & benrayana.aniss@iresa.agrinet.tn \\
\hline
\end{tabular}

\section{Embassy}

11. Embassy of the Kingdom of the Netherlands

Address: 6-8 rue Meycen, 1082 Cité Mahrajène, Tunis

\begin{tabular}{l|l|l|l}
\hline Name & Function & Phone & Email
\end{tabular}




\begin{tabular}{|l|l|l|l|}
\hline $\begin{array}{l}\text { Hans van Vloten } \\
\text { Dissevelt }\end{array}$ & Ambassador & +21671155300 & tun-cdp@minbuza.nl \\
\hline Adel Ouni & $\begin{array}{l}\text { Deputy Head of the } \\
\text { Economic Department }\end{array}$ & $\begin{array}{l}+21671155303 \\
+21698762163 \\
\text { (mobile) }\end{array}$ & adel.ouni@minbuza.nl \\
\hline
\end{tabular}

\section{Commercial actors}

\section{Carrefour}

Carrefour is a part of Ulysse Hyper Distribution and was the first Hypermarket in Tunisia. Currently they run 1 Hypermarket in Tunis and 48 Carrefour Market and 39 Carrefour Express supermarkets all over the country.

\begin{tabular}{|l|l|l|l}
\hline Name & Function & Phone & Email
\end{tabular}

\begin{tabular}{l|l|l|l}
\hline Mourad Hichri & Manager fresh products & +21671940482 & Mourad.hichri@utic.com.tn
\end{tabular}

\section{Advans}

Advans Tunisia is a microfinance institution, member of the Advans group, an international microfinance network. Created in 2013 at the initiative of Advans SA, with the support of investors and international and Tunisian partners, then approved by the Tunisian Ministry of Finance, Advans Tunisia started its activities on March 13, 2015.

\begin{tabular}{|l|l|l|l|}
\hline Name & Function & Phone & Email \\
\hline Aymen Taboubi & Agricultural operations & +21629808620 & ataboubi@advanstunisie.com \\
\hline Elliott Saint Gilles & Project Agriculture & +21629916481 & Esaint-gilles@advanstunisi.com \\
\hline 14. Potato exporters & Phone & Address & Product \\
\hline Name & $\begin{array}{l}98644751 / 75710 \\
633 / 75710633\end{array}$ & $\begin{array}{l}30 \text { Rue Said abou baker 1001 } \\
\text { Tunis }\end{array}$ & Divers \\
\hline ALI GHARBI & Fax: 32404 341 & $\begin{array}{l}\text { Espace Tunis B3- 2 } \\
\text { Montplaisir, 1073 Tunis }\end{array}$ & $\begin{array}{l}\text { artichaut, pomme de } \\
\text { terre }\end{array}$ \\
\hline IDEAL AGRO & $\begin{array}{l}93056678 / 72257 \\
884\end{array}$ & $\begin{array}{l}\text { 35, Rue Mokhtar Attia 1000 } \\
\text { Tunis }\end{array}$ & $\begin{array}{l}\text { pomme de terre, } \\
\text { tomato }\end{array}$ \\
\hline MED FRUIT ET LEGUMES &
\end{tabular}

\section{Supporting organisations}

\section{FAO}

FAO is a specialized agency of the United Nations that leads international efforts to defeat hunger. Serving both developed and developing countries, FAO acts as a neutral forum where all nations meet as equals to negotiate arguments and debate policy.

\begin{tabular}{|c|c|c|c|}
\hline Name & Function & Phone & Email \\
\hline Ahmed Bougacha & $\begin{array}{l}\text { Assistant au Représentant de la } \\
\text { FAO en Tunisie Programme }\end{array}$ & & ahmed.bougacha@fao.org \\
\hline Michael George Hage & coordinator North of Africa & & Michael.hage@fao.org \\
\hline
\end{tabular}




\section{Annex 2 Persons and organisations visited}

During the field visit in total 16 people were interviewed in 10 interviews. For the potato sector following interviewees were relevant:

\begin{tabular}{|c|c|c|c|c|c|}
\hline & Name & From & Function & E-mail & Phone \\
\hline 1 & $\begin{array}{l}\text { Dr. Chniter } \\
\text { Mohammed }\end{array}$ & $\begin{array}{l}\text { National Institute } \\
\text { of Agronomy, } \\
\text { Tunis (INAT) } \\
\end{array}$ & assistant & chniter2005@yahoo.fr & +2150973105 \\
\hline 2 & $\begin{array}{l}\text { prof Djemali } \\
\text { Mnaouer }\end{array}$ & $\begin{array}{l}\text { National Institute } \\
\text { of Agronomy, } \\
\text { Tunis (INAT) }\end{array}$ & & mdjemali@webmails.com & \\
\hline 3 & Aymen Taboubi & Advans & $\begin{array}{l}\text { Agricultural } \\
\text { operations }\end{array}$ & ataboubi@advanstunisie.com & $\begin{array}{l}+21 \\
629916481 \\
\end{array}$ \\
\hline 4 & $\begin{array}{l}\text { Elliott Saint } \\
\text { Gilles }\end{array}$ & Advans & $\begin{array}{l}\text { Project } \\
\text { Agriculture }\end{array}$ & $\begin{array}{l}\text { esaint- } \\
\text { gilles@advanstunisie.com }\end{array}$ & $\begin{array}{l}+21 \\
629916481 \\
\end{array}$ \\
\hline 5 & Ismail Ghezal & $\begin{array}{l}\text { Vegetables } \\
\text { Professional } \\
\text { Group }\end{array}$ & $\begin{array}{l}\text { Directeur } \\
\text { Général }\end{array}$ & ghezal.iagronome@gmail.com & $\begin{array}{l}+21 \\
671285522\end{array}$ \\
\hline 6 & $\begin{array}{l}\text { Ezzeddine ben } \\
\text { Mustapha }\end{array}$ & $\begin{array}{l}\text { Syndicat des } \\
\text { Agriculteurs de } \\
\text { Tunisie }\end{array}$ & $\begin{array}{l}\text { Membre du } \\
\text { bureau exécutif; } \\
\text { farmer in Utique }\end{array}$ & benmustaphaezedin@gmail.com & $\begin{array}{l}+21 \\
671897211 \\
+21 \\
620333461\end{array}$ \\
\hline 7 & Lamine Ben Ali & Carrefour & Acquisition & & \\
\hline 8 & Mourad Hichri & Carrefour & $\begin{array}{l}\text { Responsable } \\
\text { fresh products }\end{array}$ & mourad.hichri@utic.com.tn & $\begin{array}{l}+21 \\
671940482\end{array}$ \\
\hline 9 & $\begin{array}{l}\text { Mohamed } \\
\text { Slama }\end{array}$ & $\begin{array}{l}\text { Potato farm in } \\
\text { Korba }\end{array}$ & Farmer & & \\
\hline 10 & $\begin{array}{l}\text { Faïrouz Ben } \\
\text { Salah }\end{array}$ & NOUHAD & $\begin{array}{l}\text { Advisor and } \\
\text { interim- } \\
\text { manager, } \\
\text { consultant }\end{array}$ & fairouzbensalah@gmail.com & $\begin{array}{l}+21621478 \\
309\end{array}$ \\
\hline 11 & Lamia Maamer & $\begin{array}{l}\text { Agricultural } \\
\text { Consultancy, }\end{array}$ & $\begin{array}{l}\text { Translation, } \\
\text { agriculture, } \\
\text { former PUM } \\
\text { coordinator }\end{array}$ & Lamia.maamer@gnet.tn & $\begin{array}{l}+21 \\
622333031\end{array}$ \\
\hline
\end{tabular}


Corresponding address for this report:

P.O. Box 16

6700 AA Wageningen

The Netherlands

$\mathrm{T}+31(0) 317480700$

Report WPR-804
The mission of Wageningen University and Research is "To explore the potential of nature to improve the quality of life". Under the banner Wageningen University \& Research, Wageningen University and the specialised research institutes of the Wageningen Research Foundation have joined forces in contributing to finding solutions to important questions in the domain of healthy food and living environment. With its roughly 30 branches, 5,000 employees and 10,000 students, Wageningen University \& Research is one of the leading organisations in its domain. The unique Wageningen approach lies in its integrated approach to issues and the collaboration between different disciplines. 